\title{
Institutions, industries and entrepreneurial versus advantage-based strategies: how complex, nested environments affect strategic choice
}

Article

Accepted Version

Hitt, M., A., Sirmon, D., G., Li, Y., Ghobadian, A., Arregle, J.-L. and $\mathrm{Xu}, \mathrm{K}$. (2021) Institutions, industries and entrepreneurial versus advantage-based strategies: how complex, nested environments affect strategic choice. Journal of Management and Governance, 25 (1). pp. 147-188. ISSN 1385-3457 doi: https://doi.org/10.1007/s10997-020-09504-2 Available at https://centaur.reading.ac.uk/89655/

It is advisable to refer to the publisher's version if you intend to cite from the work. See Guidance on citing.

To link to this article DOI: http://dx.doi.org/10.1007/s10997-020-09504-2

Publisher: Springer

All outputs in CentAUR are protected by Intellectual Property Rights law, including copyright law. Copyright and IPR is retained by the creators or other copyright holders. Terms and conditions for use of this material are defined in the End User Agreement. 


\section{www.reading.ac.uk/centaur}

\section{CentAUR}

Central Archive at the University of Reading

Reading's research outputs online 
Institutions, Industries and Entrepreneurial versus Advantage-based Strategies: How Complex, Nested Environments Affect Strategic Choice

MICHAEL A. HITT

Texas A\&M University

Mays Business School

Department of Management

4221 TAMU

College Station, TX 77843-4221

Tel: $979-845-6676$

Fax: 979-845-3420

e-mail: mhitt@mays.tamu.edu

$\&$

Texas Christian University

Neeley School of Business

Department of Management Entrepreneurship and Leadership

2900 Lubbock Avenue, Fort Worth, Texas 76109

Tel: 817-257-7562

DAVID G. SIRMON

University of Washington

Foster School of Business

e-mail: $\underline{\text { dsirmon@uw.edu }}$

\title{
YUAN LI
}

Tongji University

School of Economics and Management

Shanghai 200092 China

e-mail: 11liyuan@tongji.edu.cn

\author{
ABBY GHOBADIAN \\ University of Redding \\ Henley Business School \\ Whiteknights, Reading \\ RG6 6UD United Kingdom \\ e-mail: abby.ghobadian@henley.reading.ac.uk
}

JEAN-LUC ARREGLE

EM Lyon Business School

23 avenue Guy de Collongue

69134 Ecully Cedex, France

e-mail: arregle@em-lyon.com

\section{KAI XU}

University of Texas at San Antonio 
College of Business

Department of Management

San Antonio, TX 78249

e-mail: kai.xu@utsa.edu

Key Words: Entrepreneurial Strategies, Defensive Strategies, Institutions, Industries, Environmental Complexity, Strategic Choice

To be published at Journal of Management and Governance 
INSTITUTIONS, INDUSTRIES AND ENTREPRENEURIAL VERSUS ADVANTAGE-BASED STRATEGIES: HOW COMPLEX, NESTED ENVIRONMENTS AFFECT STRATEGIC CHOICE

Abstract

With primary and secondary data on 658 firms from 17 countries across three continents, we examine the combined influence of country-level institutions on industry attributes and in turn their effects on the choice of a defensive advantage-based strategy and an entrepreneurial strategy. We find that strong and efficient institutions constrain both dynamism and munificence in industries. In turn, industry dynamism has a negative effect on both entrepreneurial and advantage-based strategies. However, firms having strong relational capital with important stakeholders can better navigate these uncertain environments to employ both strategies with increasing strength Alternatively, in more munificent environments, firms are less likely to employ advantage-based strategies and more likely to employ entrepreneurial strategies. This study demonstrates the environmental conditions under which firms are more-or-less likely to employ entrepreneurial strategies and defensive advantage-based strategies.

Key Words: Entrepreneurial Strategies, Defensive Strategies, Institutions, Industries, Environmental Complexity, Strategic Choice 


\section{INSTITUTIONS, INDUSTRIES AND ENTREPRENEURIAL VS ADVANTAGE-BASED STRATEGIES: HOW COMPLEX, NESTED ENVIRONMENTS AFFECT STRATEGIC CHOICE}

\section{INTRODUCTION}

Kuratko (2009) suggested that there is a global innovation revolution in which economic development is catalyzed by entrepreneurship and innovation. However, although this is a global phenomenon, entrepreneurial outputs are not evenly distributed across countries. Surprisingly, in several developed countries, such as those in Western Europe and North America, the extent of entrepreneurial activity has declined over the last 15 years (Porter, 2018). Yet, it seems reasonable to expect that the resources available in these countries should provide for effective entrepreneurial efforts and continued renewal, but the recent data belie this conclusion. Because corporate entrepreneurship is often critical for building and maintaining competitive advantages (Kuratko, 2015), pinpointing the cause for lower entrepreneurial activity is important. Some scholars suggest that entrepreneurial activity is influenced by institutions; economic and regulatory policies, for example, can serve as important precursors to entrepreneurial activity (Feldman, 2014; Spencer and Gomez, 2004). Others argue that industry competition plays a critical role in the promotion or constraint of entrepreneurial activity (Dess, Lumpkin, and Covin, 1997).

Conceivably, both country-level institutions and industry attributes matter, especially in combination, but we need to better understand how they do so. As such, research is needed to identify the combination of environmental conditions under which entrepreneurial activities flourish and those that motivate firms to adopt entrepreneurial strategies instead of defending current advantage(s).

Sirmon, Hitt, and Ireland (2007) identified two primary types of strategies which firms use to leverage their resources to compete within their environmental contexts. The first strategy identifies and leverages a specific capability that helps the firm achieve and maintain an advantage over rivals. A capability advantage strategy is intended to provide value to customers that is superior to the value that rivals can provide. This strategy does not entail entrepreneurial activity, however. The second strategy is an entrepreneurial strategy by which firms seek to exploit existing or new opportunities in the marketplace. Over the last few decades, research on the resource-based view of the firm has matured (Barney, 2001; Barney, Ketchen and Wright, 2011). In recent years, research in this stream has helped us to understand that managers make explicit decisions regarding structuring, bundling and leveraging of their firm's internal resources to support entrepreneurial and more stable strategic activities (Sirmon, Hitt, Ireland and Gilbert, 2011), but we need a better understanding of how the external environment stimulates such 
decisions (Aguilera, Judge, and Terjesen, 2018; Murray, 1984; Sirmon, et al., 2011). Therefore, the purpose of this research is to identify how country-level institutions (policies, rules, and norms) and industry-level conditions (those influencing competitive actions) together affect the type of strategy the firm enacts.

There has been significant debate and research, from multiple scholarly traditions, regarding the effects of the external environment on organizational outcomes of interest (see Fitza, 2014). Broadly, contingency theory research has suggested that organizational attributes are often influenced by the organization's external environment (Donaldson, 2001). For example, Bamiatzi, Bozos, Cavusgil, and Hult (2016) compared how country-, industryand firm-level attributes affect profitability (e.g., in developed versus emerging markets and in adverse versus stable economic conditions). While stemming from different scholarly traditions, related research provides evidence that both the competitive environment (Porter, 1980) and country-level institutions (Holmes et al., 2013) directly influence firms' enacted strategies. However, more research is needed to help us understand the specific conditions under which firms are more likely to engage in an entrepreneurial or an advantage-based strategy. Additionally, while the research streams on environmental effects have advanced our knowledge, despite the theoretical promise of integration, they have yet to provide a more integrated and holistic view of how the gestalt of environmental factors influence firm strategies. Therefore, beyond the independent effects of specific environmental factors, there is need for a more elaborated understanding of how composite formal country-level institutions and industry-level environments are interrelated and how they jointly influence the choice of firm strategy. Indeed, some research suggests that the combined effects of industry- and country-level institutions are more influential than their independent effects (McGahan and Victer, 2010; Tong et al., 2008).

There are several levels of environmental factors. While regional similarities exist, countries differ in their institutions (Arregle et al., 2013, 2016; Berry, Guillén, and Hendi, 2014). Country-level institutions represent a super-ordinate influence on participants by creating 'rules of the game' (North, 1990) that affect their behavior (McGinnis, 2011). According to North (1990) and Scott (1995), formal institutions are composed of codified and explicit rules and standards that shape behavior in a society. Thus, country-level formal institutions constrain some behaviors while incentivizing others, (e.g., regulations related to bank assets, loan procedures and financial cost structure). Specifically, formal country-level institutions such as regulatory, political and economic institutions commonly influence more proximal industry-level environments. For example, economic institutions such as the U.S. Federal Reserve's actions to control the money supply and govern the interest rates in turn influence the 
general resources available in particular industries (i.e., munificence) and the amount of change and uncertainty within industries by encouraging or bounding market demand (i.e., dynamism). Together these two levels of environments (i.e., institutions and industry) impinge on the existence of so-called global industries. While some cross-boundary industries display common characteristics, evidence shows that there is considerable variance among industries across countries (Bamiatzi et al., 2016). Part of the reasons for differences relates to the formal institutions in the country. For example, economic policies vary across countries and therefore, the costs of doing business, such as the interest rates charged to access debt capital, also vary. Additionally, educational infrastructure varies across countries and thus, there may be differential access to skilled labor and capabilities with the same industry in two different countries. The total environmental context involves a complex set of nested factors. Country-level institutions have combinative influences on industry attributes (reflecting institutional complexityHitt, 2016; Hitt and $\mathrm{Xu}, 2019$ ), which in turn lead to industry norms that, then, influence the firm behavior, including strategic choice (Spender, 1989). All told, a more complete understanding of how the environment affects strategic choice requires scholars to examine how these complex, nested environmental factors filter down to managerial decisions.

Herein, we advance knowledge by developing theory arguing that country-level formal institutions indirectly affect firm strategies via industry-level attributes. We describe how distal country-level formal institutions affect key industry attributes (dynamism and munificence) which in turn influence managers' decisions to implement an entrepreneurial versus a capability-focused strategy. Specifically, we argue that these industry attributes incentivize or constrain rivals' competitive actions that in turn, provide parameters for the selection of particular strategy. There has been considerable research on the general influences of industry attributes on firm behavior (Dess and Beard, 1984; Dess, Ireland, and Hitt, 1990; Keats and Hitt, 1988) and on the more distal influences of individual country-level institutions on firm behavior (Hitt, Li and Xu, 2017; Holmes, Miller, Hitt and Salmador, 2013; Peng, Sun, Pinkham and Chen, 2009). However, our theory and results contribute to knowledge in the field by examining how complex country-level institutions indirectly affect firm behaviors via industry-level attributes that have direct effects on them, particularly the enactment of entrepreneurial and advantage strategies. Indeed, our results suggest that the effects of formal country-level institutions on firms' strategies are indirect, enacted through the industry-level attributes of munificence and dynamism. In addition, we find the relationship between industry dynamism and firm strategy is moderated by a firm's relational capital (strong and embedded 
relationships between the firm and its key stakeholders) such that key stakeholders provide support and resources that help the firm to manage uncertainty (and thereby enhancing the use of an entrepreneurial strategy). In total, while some have argued that strategies are affected by the environment and linked to performance (Sirmon et al, 2007; Sirmon and Hitt, 2009), research on specific mechanisms linking these factors is extremely limited. Thus, in addition to increasing our understanding of institutional complexity, we also expand our knowledge of how specific environmental conditions prompt firms to engage in entrepreneurial and current advantage-based strategies. Figure 1 depicts our theoretical model.

\section{Insert Figure 1 about here}

\section{THEORETICAL FRAMEWORK}

When forming strategies, executives consider their environmental context (Hitt, Keats, and DeMarie, 1998). Their environmental context is complex and multifaceted with sets of integrated institutions comprising a country-level institutional system within which firms are embedded and must maneuver to gain a competitive position relative to rivals in specific industries (Batjargal et al., 2013; Ostrom, 2005; 2010). We begin by examining national institutions.

\subsection{Complex formal country-level institutions}

The institutional system has multiple centers of power and authority producing different pressures that affect industries and in turn firms' strategies and behaviors. National formal institutions are largely implemented by government organizations through formalized and coded rules and policies to regulate and constrain firms' actions. Research has shown that country institutions influence how firms manage their resources and the strategies they formulate (Chan, Isobe, and Makino, 2008; Lu et al., 2010; Meyer et al., 2009; Peng et al., 2009; Peng, Wang, and Jiang, 2008). For instance, environmental taxes in UK on energy production affected the industry's munificence. Specifically, these taxes raised $\$ 70$ billion in 2014 (ONS, 2015) thereby increasing the production costs of coalbased power generators and incentivizing the switch to gas. These changes affect the costs in related industries such as refineries, chemicals, etc. (Grover, Shreedhar, and Zenghelis, 2016). Moreover, this policy has enhanced dynamism in the renewable energy industry and increased the resources flowing to it thereby boosting its munificence.

Nationally, different government organizations basically represent major centers of power such as regulatory power, political power, and economic power. These government agencies develop the policies and/or 
implement the policies developed by others (e.g., administrative and legislative branches) thereby representing the institutions. Regulatory institutions include a set of rules and legal requirements which regulate and/or limit firm or industry behaviors for the sake of the social welfare (Bekaert, Harvey, and Lundblad, 2005; Li, 2010; Spicer, McDermott, and Kogut, 2000); Political institutions represent the application and enforcement of laws and the development of policies related to societal responsibilities (Hillman and Keim, 1995; Henisz, 2000; Persson, 2002); Economic institutions are composed of multiple monetary and fiscal policies and rules that govern and/or influence the availability and value of the society's financial resources, which in turn support capital investments (Fischer, 1993; Lucas, 2003; Levine and Zervos, 1998). Importantly, Greenwood, Raynard, Kodeih, Micelotta, and Lounsbury (2011) argue that the institutional environment is pluralistic. These multiple institutions have complex interdependencies that have simultaneous and often combined effects. Oberthur and Locke (2011) argue that sets of institutions co-govern.

Due to their interdependent and collective effects, institutions influence behaviors in a multifaceted, integrated manner. Thus, individual effects of a specific national-level formal institution may be difficult to identify as its influence becomes integrated with those of other institutions (Acemoglu, Johnson, and Robinson, 2005; Sobel and Coyne, 2011). For example, economic policies might be designed to encourage new investments to spur economic activity. Yet, while new innovative activity (through increases in R\&D investments) may be one of the goals of such economic policies, regulations on patents bureaucratic requirements including the time necessary for a patent to be granted may discourage those investments. So, lower costs of capital might seemingly encourage a pharmaceutical firm to increase its investments in R\&D to discover new drug. However, the significant requirements to gain approval to take a new drug to the market might encourage that firm to use the lower cost capital to seek an acquisition of another firm with valuable patented drugs. However, other regulations could delimit a merger of two major pharmaceutical firms if it would create too much concentration of market power in the hands of the newly merged firm in violation of anti-trust laws. Thus, a country's formal institutions combine to establish the 'general rules of the game' (North, 1990) through prescribed (formal) rules and standards.

This composite set of interdependent institutions characterizes an institutional order (Ostrom, Schroeder, and Wynne, 1993). The national formal rules and standards influence industry attributes, which influence rivals' competitive actions and cumulatively the formation of industry-level practices and norms that serve as parameters 
for managers' strategic choices. Indeed, the shared understandings (collective beliefs) on entrepreneurial strategies in an industry, are reinforced by competitors' imitation and legitimization (Navis and Glynn, 2010).

\subsection{Industry environment}

The industry environment includes important industry attributes and their corresponding norms and practices. Industry attributes, munificence and dynamism, represent the industry capacity and stability (Dess and Beard, 1984), and influence firms' strategies and behaviors by shaping industry-level norms that develop over time. These industry norms are collections of stable shared logics that constrain firms' actions. ${ }^{1}$ For example, munificence in industries influences the norms on risk taking (which in turn affect the types of strategies employed).

Alternatively, in high technology industries (dynamic industry environment), there often are informal norms regarding hiring scientists and professional employees from rivals to protect intellectual property (e.g., the norms for not poaching other high technology employees among major companies such as Apple, Google, and Intel were supposedly violated by Palm - Whitney, 2013). These norms create industry-level pressures for firms to conform in order to gain legitimacy. Indeed, firms often exhibit mimetic behaviors in accordance with industry norms because doing so reduces ambiguity and uncertainty and contributes to the firm's legitimacy in the market (Benner and Tripsas, 2012; DiMaggio and Powell, 1983; Haveman, 1993). In fact, Haveman (1993) observed that firms mimic the more similar or successful firms in the industry as a response to environmental uncertainty. Although some firms may purposely pivot from the shared logic in order to differentiate from industry rivals, such actions are highly risky. Deviations from the norms in the industry can trigger concerns about legitimacy, thus these entrepreneurial behaviors can potentially threaten the survival of the firms (Alessandri and Khan, 2006; Jose, Nichols and Stevens, 1986). Therefore, even if some firms can be entrepreneurial in ways that deviate from these norm-based industry practices, their deviations are commonly limited.

Industry-level attributes of munificence and dynamism also have complex effects. For example, dynamic industries are characterized by major changes and even external jolts that disrupt the status quo. These industries

\footnotetext{
${ }^{1}$ Dess and Beard (1984) originally proposed three primary environmental attributes, dynamism: munificence and complexity. Complexity was defined as the number of elements in a firm's task environment with which it had to deal. Keats and Hitt (1988) examined the effects of all three environmental attributes on firms' corporate strategy (i.e., product diversification) and their organizational structure. Although they found both dynamism and munificence to affect the firms' strategy, complexity affected neither strategy nor structure. They found that complexity was only related to firm size (positively). Since that time, more studies have examined the effects of dynamism and munificence to the exclusion of complexity especially when the research focused on firm strategy. Given the interest of our study on firm strategy, we limited our research to dynamism and munificence.
} 
are characterized by uncertainty in which the environmental changes are difficult to predict. Industry dynamism often requires firms to make rapid strategic changes to adapt to the environment without which may lead to an immediate performance loss in fast-changing industries (Keats and Hitt, 1988). Munificence, an indicator of the resource availability, also affects firm outcomes (Eriksson, 1984). Industry munificence influences strategic choices designed to capitalize on environmental opportunities (Keats and Hitt, 1988) and helps firms to be more entrepreneurial (Hitt et al., 2011).

Industry munificence and dynamism can affect firms' strategic choices for several reasons. For example, in dynamic environments, rivals' competitive actions imitating successful firms yield industry norms that economize search costs (Cyert and March, 1963). Alternatively, dynamic industries also present opportunities for developing innovations that can change demand in the market. Additionally, in less munificent industry environments, following norms (isomorphism) provides firms with legitimacy and access to limited resources. In fact, isomorphism can be especially strong within industries to satisfy the multiple industry stakeholders' (e.g., customers, suppliers, etc.) requirements (Aldrich and Martinez, 2015; Jain, Aguilera, and Jamali, 2017). Yet, munificent environments provide the resources and thus the flexibility to consider a broader set of strategic choices.

\subsection{Complex formal country-level institutions influence on industry attributes}

The influence of distal country-level formal institutions often flows through specific industry attributes to affect managerial decisions. For example, the national regulatory institutions may largely or partly determine attributes such as the resource availability and resource allocation in one industry or across several industries (Oliver, 1999). Likewise, economic institutions strongly influence capital availability, distribution and market liquidity (and thus munificence) in an industry (Batjargal et al., 2013). Some formal national institutions may target specific industries (e.g., specific regulations) such that industry norms are developed to allow firms within that industry to effectively respond and satisfy the requirements (e.g., regulatory requirements). In other cases, national institutions such as economic policies may affect multiple industries, yet the effects vary across industries. For example, economic policies to lower the interest rates have greater effects on firms in industries where capital costs are high and/or the cost of capital is important for the purchase of the firms' goods.

Moreover, industry attributes have more proximal influences (direct effects) on firms' strategic choices than do national institutions for several reasons. First, the industry's leading firms and external stakeholders often 
decide how to interpret the national institutions because of their advantageous position in the industry and the abundant industry information they possess (thereby also providing leadership in the development of industry norms based on these institutions). In fact, other firms in the industry often try to imitate industry leaders and frequently perform well even when their imitation of the leaders' strategies is imperfect (Posen, Lee and Yi, 2013). Industry leaders may even have the power to influence the institutions through lobbying activities (Hillman and Keim, 1995). Second, external stakeholders of an industry, such as suppliers, customers, employees, and investors have expectations for firms' strategic choices (Jain et al., 2017). Many of these expectations are based on industry norms. Third, although conformity to the national institutions helps to achieve a degree of legitimacy, the industry attributes and resulting norms also influence the resource allocations to industry participants (Anderson and Tushman, 2001). Fourth, conformity to the industry norms and achievement of legitimacy in an industry lessens the threat emanating from any decoupling of its behaviors from the national institutions (Young and Marais, 2012). Therefore, the proximal nature of industry conditions makes them especially relevant for managers' strategic decisions. For example, the industry context is a major source of market opportunities for revenue and profits that influence firm survival and success (Dess, Ireland and Hitt, 1990).

Based on these notions, we next develop theoretical arguments and hypotheses related to the complex nested effects of environmental factors that influence firm behavior; some of these effects are direct while others are indirect. We start by explaining the indirect effect of how the efficiency of formal national institutions affects two key industry attributes: dynamism and munificence.

2.3.1 Country-level institutions and industry dynamism. For some time, industrial-organization economists have argued that industry structure is a major determinant of firm profitability (e.g., Schmalensee, 1985). Indeed, strategic management scholars have found empirical support for these arguments (Rumelt, 1991). More recently, Short, Ketchen, Palmer, and Hult (2007) found that industry accounted for a significant portion of the variance in firm performance, but firm factors also had a strong influence. Yet, country-level institutions also influence industry structure and other attributes (Chang and $\mathrm{Wu}, 2014)$. For example, regulatory institutions sometimes target rules for specific industries, while other regulatory institutions (e.g., requirements for financial transparency and related corporate governance regulations) have a broader impact across industries. Likewise, the economic institutions can influence the munificence of resources (e.g., capital available and the costs of that capital) available in industries and thereby affect the amount and intensity of competitive rivalry within an 
industry. For example, greater access to capital lowers entry barriers thereby increasing the number of new entrants into an industry which in turn produces higher rivalry (Anderson and Tushman, 2001). These institutions, then, provide incentives for economic activity while simultaneously placing constraints on the behavior of actors (e.g., in an industry) through the formal rules issued and enforced. The prescription of rules to guide actors' decisions and behaviors increase conformity among the actors. Thus, while certain institutions promote and/or support economic activity, other institutions are designed to bound that activity in order to limit the amount of uncertainty in the markets.

The constraints on the actors' behaviors also limit the variance in outcomes and thus restrict the amount of instability and uncertainty. These limitations are likely to restrict the strategic choices within an industry lessening the degree of change possible. As such, strong and efficient national institutions generally restrain the amount of dynamism by providing order and structure within an industry. For example, firms in high technology industries often engage in rivalry based on innovation which in turn produces continuous and often disruptive change. Substantial dynamism in an industry produces uncertainty and instability which creates challenges for strategic decision makers. However, clear regulations often delimit certain types of action and/or limit actions to a specified set that are acceptable (Nelson, 1986; Sabel, Herrigel and Kristensen, 2018). Thus, while rivalry can be fierce, strong, and efficient, national-level institutions can limit the breadth of actions, thereby limiting dynamism. Obviously ambiguous or overly restrictive regulations can promote outlier behavior either because the requirements are unclear, or the limitations are so severe, that firms either have to leave the industry or engage in unsanctioned behavior to survive. In either case, these regulations are inefficient. Alternatively, economic institutions are commonly designed to promote measured economic growth and to limit substantial variations (e.g., controls on interest rates and providing economic stimulus). In strong political democracies, government leaders are responsible to their constituents and thus must enact policies that they desire (March and Olsen, 1983; Wallis, 1999). In most cases, constituents prefer measured growth with low uncertainty. As such, policies are enacted that limit abrupt changes in most sectors. In summary, strong, efficient country-level institutions constrain the amount of dynamism present in most industries.

Hypothesis 1a: Strong and efficient country-level formal institutions are negatively related to industry dynamism.

2.3.2 Country-level institutions and industry munificence. Political leaders desire to have strong economies that provide full employment. Thus, as noted previously, some institutions provide incentives designed 
to enhance market development and economic growth. Alternatively, some institutions also place constraints on economic activity within industries (Casper, Lehrer and Soskice, 1999). Although munificent conditions are generally more preferable for the support of economic growth, there are some negative consequences of highly munificent environments. For example, high economic growth based on increasing demand for goods (economic policies such as reduction in taxes produce more disposable income leading to higher demand for goods) often leads to increasing inflation. In turn, inflation (higher prices for goods) reduces demand for goods and thus leads to slowing economic growth (Barro, 2013). Countries with strong economic institutions commonly have policies in place that are designed to moderate the rate of inflation (e.g., higher interest rates which also tends to reduce demand over time) (Pollin and Zhu, 2006). Additionally, regulations that are designed to limit certain kinds of actions and/or outcomes not desired by major constituencies may restrict access to resources or increase costs that reduce munificence in an industry (e.g., requirements for the amount of capital a bank must hold that in turn restricts their lending capacity). One way in which costs can be increased is through special taxes that are more likely to be imposed in highly munificent environments than those with low munificence (Andrews and Johansen, 2012). Additionally, high munificence in an industry may also be achieved by unsustainable consumption of natural resources. Regulations designed to restrict actions that might damage the environment may limit access to some natural resources such as oil and minerals or greatly increase costs to control pollution (e.g., costly equipment to reduce or eliminate emissions of pollutants into the air or water at manufacturing/processing plants) (Bansal, 2002). Strong institutions (e.g., strong political democracy) are likely to produce rules that try to achieve relative balance in the munificence across industries, especially in cases where the munificence in one industry occurs at the expense of resources scarcity in another industry.

The discussion above explains the influence of multiple institutions on industry munificence; some are designed to enhance munificence while others are designed to constrain it within limits. Thus, the combinative effects of formal country-level institutions are not intended to minimize munificence but rather to bound it to provide a balance of resources available across industries and throughout the economy and to limit the negative consequences of overly high munificence. Therefore, we expect strong, efficient institutions to place limits on munificence within industries.

Hypothesis 1b: Strong and efficient country-level formal institutions are negatively related to industry munificence. 


\subsection{Industry attributes and firm strategy}

Industry dynamism and munificence have specific influences on firm behaviors. For example, Bradley, Shepherd, and Wiklund (2011) found that when facing dynamic and less munificent environments, managers work to maintain resource slack. And, these attributes affect the focal firm and rivals, increasing the importance of managing resources to gain or maintain a desired competitive position in the market. In doing so, managers must analyze and understand (make sense of) their environments including the behaviors of rivals and design their strategic actions accordingly (Narayanan, Zane, and Kemmerer, 2011).

Indeed, a large part of this 'sensemaking' involves carefully observing, understanding and sometimes imitating or adapting to primary industry rivals. Thus, industries evolve, through the cumulative competitive actions by rivals and their results, such that firms accept common norms and engage in similar practices in an industry. In fact, Porac, Thomas, and Baden-Fuller (2011) argue that 'cognitive communities' develop within industries where shared beliefs among rivals' managers based on their common industry experience result in similar firm behaviors. Spender (1989) refers to commonly expected industry-specific practices as industry recipes or what most participants understand as industry norms. Thus, industry recipes provide norms of behavior important for achieving legitimacy and/or managing uncertainty, given identifiable industry attributes. Indeed, Clarysse, Bruneel, and Wright (2011) show that firm growth is affected by how firms use their capabilities to operate within their environment.

Next, we consider how these industry attributes, and the related shared norms, affect the strategies firms use to gain or maintain a competitive position in the marketplace.

2.4.1 Dynamism and firm strategies. Firms can employ two general strategies to create superior value for their customers: exploit a capability advantage (use current capabilities to defend an advantage in order to maintain or increase market share or geographic scope) or create/exploit entrepreneurial opportunities (e.g., create and/or enter new markets or market niches) (Sirmon et al, 2007). While they may employ both strategies each for different product lines/market niches, they commonly emphasize one more than the other. The implementation of both strategies is influenced by the dynamism in the industry (Baum and Wally, 2003).

Significant change in an industry creates substantial uncertainty. If change is extensive and continuous, the firm's market offerings and/or market position may need to be modified. In such situations, a strategy to exploit the firm's current valuable capabilities (or resources) at best can only result in a temporary short-term advantage, 
making that strategy less desirable. With continuous change, the value of any capability is unlikely to remain stable and probably will decline without enrichment. In fact, Danneels (2012) found the strategy to build on and promote a capability advantage was effective only in stable and moderately competitive conditions. Thus, in a highly dynamic industry environment, the capability on which an advantage is based will have to change frequently, because it will have to be new/unique or substantially enriched to sustain the firm's competitive advantage. Indeed, an industry with high dynamism often requires flexibility (acquiring new knowledge) and innovation (Miller and Shamsie, 1996) which are unlikely to occur with a capability advantage strategy. Thus, if a firm tries to defend its current advantage in this environment, the firm will probably lose its competitive advantage.

Hypothesis 2a: Industry dynamism is negatively related to the use of a capability advantage strategy. Alternatively, dynamic environments with significant uncertainty provide entrepreneurial opportunities (McGrath and MacMillan, 2000) in which there is potential to gain a unique advantage over rivals through innovation, even though the risks are high. In fact, firms may need to take actions (e.g., develop innovative products) that provide them with the flexibility to navigate effectively within the uncertainty created by environmental changes. Identifying those opportunities and exploiting them requires an optimistic gain-oriented approach and a willingness to accept risk (Hmieleski and Baron, 2008). However, to successfully exploit the opportunities also requires the ability to overcome significant challenges. For example, it is difficult to develop and successfully introduce a new product or to identify and serve a new market (i.e., creating demand where none existed previously) especially in a dynamic environment with significant and unpredictable change producing significant uncertainty (Dess and Beard, 1984). As such, Keats and Hitt (1988) found that under dynamic and highly uncertain conditions, firms tended to centralize decision making and become more conservative in their decisions. Additionally, Davis, Eisenhardt, and Bingham (2009) found that firms used simpler rules in more dynamic environments. They are more conservative in the commitment and use of their resources. As such, these firms become more rigid and inflexible and thus do not invest as needed to create innovations and new market opportunities (McKinley, Latham, and Braun, 2014). The unwillingness to be more innovative and attempt to create new markets is more common among the industry leaders because they are trying to protect their leading market positions (avoid losses) rather than to achieve new market gains (Shimizu, 2007). When industry leaders remain more static by focusing on their current products and markets in a dynamic environment, it presents opportunities for firms to be more entrepreneurial and disrupt the market overtaking the market leaders. Yet, because of the uncertainty created by significant change (Mahnke, 
Venzin \& Zahra, 2007), many firms in the industry are unsure of the proper strategic direction, and thus are most likely to imitate market leaders, assuming that is the safest strategy. They may build slack resources but then they are unlikely to use them other than as a reserve to protect against failure in an uncertain environment (Bradley et al., 2011). Therefore, isomorphic tendencies in highly dynamic industries are likely to produce firms that are more rigid and less innovative. An entrepreneurial strategy is risky because of the unpredictable nature of the environment, thus the significant uncertainty in such environments causes most firms to become risk averse. Therefore, while a few firms might engage in an entrepreneurial strategy in a dynamic environment, due to the uncertainty and risk in this environment, we expect most to imitate market leaders, remain rather static and build slack.

Hypothesis 2b: Industry dynamism is negatively related to the use an entrepreneurial strategy.

2.4.2 Moderating effects of relational capital. Responding effectively using either strategy in a dynamic environment likely requires support from key stakeholders. Thus, relational capital with important stakeholders facilitates the enactment of the firm's strategies by providing access to the requisite information and knowledge needed to deal with the uncertainty created by dynamic environments (Eisenhardt, 1989).

Firms employing a strategy to maintain a current capability advantage in a dynamic industry environment will likely have to establish a series of temporary competitive advantages with a short-term focus for each advantage (Sirmon et al., 2010). Doing so requires the firm to make regular incremental improvements in the capability(ies) on which the advantage is based. To do this effectively, the firm needs a steady flow of resources/information that allow it to update the capability(ies) and enhance the firm's ability to manage the uncertainty to maintain its advantage. A primary means of ensuring access to resources and information about the market and other factors that contribute to the uncertainty is building strong relational capital that entails embedded relationships. Embedded relationships exhibit trust between the partners, information exchange and even joint problem solving (Uzzi, 1997). For example, embedded relationships with financial firms provides more ready access to financial resources (e.g., partly because of trust) that may be needed to improve current capabilities to achieve a temporary advantage. Relationships with financial firms and suppliers provide access to other resources (e.g., other stakeholders in the community) and information about markets (and competitors) that reduce the uncertainty for the firm (Huang, Yen and Liu, 2014; Ruida-Manzaneres, Aragon-Correa and Sharma, 2007). Additionally, effective relationships with government entities provide information on formal institutions that influence dynamism and potential or impending changes in relevant policies and regulations and likely means of implementation thereof (Sun, Mellahi and Wright, 2012). 
Strong relationships with the stakeholders identified above provide legitimacy to the focal firm (Dacin, Oliver and Roy, 2008) which can be important to other stakeholders (e.g., customers, employees) especially in a dynamic (uncertain) environment (Hormiga, Batista-Canino and Sanchez-Medina, 2011). Thus, strong relational capital helps firms to manage and reduce the negative effects of dynamism on a capability advantage strategy.

Hypothesis 2c: Relational capital positively moderates the relationship between industry dynamism and the use of a capability advantage strategy.

Although we noted earlier that firms often become more centralized and institute simpler rules to guide their strategic behavior when there are significant and continuous or even discontinuous changes in their industry, we also suggested that to be competitive over time, firms likely need to engage in entrepreneurial behavior (e.g., innovation) seeking to adapt to these changes. Yet, these responses are not necessarily exclusive. Instead, innovation can thrive in firms where an entrepreneurial focus is centrally supported and simple rules allow for speed and flexibility in responding to opportunities (e.g., Hitt et al., 1998).

Building and maintaining entrepreneurial capabilities (to identify new market needs, develop creative ways of meeting those needs and implementing them successfully such as bringing new products to the market) are attributes of firms most likely to succeed in a dynamic industry environment (Sirmon et al., 2007). To build and apply these capabilities, however, requires that the firm develop mechanisms for dealing with the uncertainty and ambiguity in the environment (i.e., they need to reduce their uncertainty) (Anderson and Tushman, 2001). Some firms reduce their uncertainty by becoming centralized and more rigid (Keats and Hitt, 1998). An additional means for reducing uncertainty and ambiguity is by building strong relationships with important external stakeholders, i.e. embedded relationships as noted earlier (Hitt, Bierman, Uhlenbruck and Shimizu, 2006). For example, firms having strongly embedded relationships with financial firms have better access to the financial resources necessary to invest in creating innovative products and in commercializing them. Bankers are often wary of providing resources for risky investments especially in an uncertain economy, but the embedded relationship gives them access to more knowledge and information about the focal firm and produces trust between the parties (Hitt et al., 2006). Additionally, suppliers can provide access to information that helps the firm to identify new market opportunities. Embedded relationships with suppliers ensure that external resources and supplies will be available when needed and that the supplier will help to jointly solve problems such as those encountered in the development of new products (Sobrero and Roberts, 2002). Strong relationships with government entities can provide access to information about regulations and economic policies, how to interpret them and to anticipate changes in them. The 
firm may even be able to convince the government units to enact formal institutions that benefit the industry and perhaps of value to the firm (Hillman and Keim, 1995). Thus, strong positive relational capital with key external stakeholders reduces the negative effects of high dynamism and allows the firm to better manage the uncertainty. As a result, relational capital facilitates a strategy to create new market opportunities.

Hypothesis 2d: Relational capital positively moderates the relationship between industry dynamism and the use of an entrepreneurial strategy.

2.4.3 Munificence and firm strategies. The use of the two types of strategies is also influenced by the level of munificence in the industry environment. In general, higher levels of munificence in the environment are desirable because it provides greater access to the resources needed to survive and be successful (Cottier and Santalo, 2014). However, when munificence is high, access to resources is open to many. Thus, the focal firm and its rivals generally have the same or similar levels of access to these resources. Additionally, greater munificence in an industry generally lowers the entry barriers, thereby inviting new rivals to enter and compete for market share (Payne, Kennedy and Davis, 2009). Lower entry barriers negatively affect industry attractiveness for current participants and influence the strategy they must employ in order to be successful (Porter, 1980; 1985). These attributes of the industry environment have critical importance for the capability advantage strategy. First, the access to resources increases the probability that rivals can imitate and potentially enrich (improve) the capability(ies) on which the focal firm's advantage is based or develop/acquire a substitute for it (Pontikes and Barnett, 2017). If they are able to imitate the leading firms' capability, rivals can then erase a competitive advantage and gain at least competitive parity (Sirmon et al., 2010). If they can imitate and improve the capability, making it better than the focal firm's capability or develop an effective and better substitute for it, they can then provide superior value to customers. If they do so, they will eliminate the focal firm's competitive advantage and 'steal' market share (Hitt, Ireland and Hoskisson, 2020).

These conditions place significant pressures on firms using a strategy to maintain a capability advantage. As noted earlier, they must plan for a series of only temporary short-term advantages requiring them to continuously update and enrich or replace their capability on which the advantage is based in order to create a new advantage (Sirmon et al., 2010). Because rivals have access to the necessary resources to imitate and improve on their capabilities, the focal firm will likely have to develop new capabilities regularly to maintain a competitive advantage (Pontikes and Barnett, 2017). Doing so will be difficult because building an advantage based on new capabilities will be temporary as munificence affords rivals the opportunity to imitate; thus, providing superior value to 
customers will be challenging except in the short term (Sirmon, Hitt, Arregle and Campbell, 2010). Furthermore, it may require new practices (routines) or at least altering their routines. As such, the capability advantage strategy is difficult to implement successfully and to sustain in this environment.

Hypothesis 3a: Industry munificence is negatively related to the use of a capability advantage strategy.

Alternatively, munificent environments provide opportunities to introduce new products to the market, as the resources are often available to invest in the development of new products. And with greater slack resources, firms are more likely to experiment and take calculated risks. Concomitantly, research shows that valuable R\&D projects are less likely to receive adequate funding in environments of low munificence, and because of this, they often fail (Levitas and McFadyen, 2009). Furthermore, munificent environments present opportunities to develop new market niches and new markets. Customers likely have more resources, may be willing to try new products (i.e., innovations) and unique products. As such, it is less risky to be entrepreneurial in munificent environments. The industry norms for munificent environments commonly promote differentiation, especially through innovation, thereby supporting behavior to develop and introduce new products for the existing market and/or for new niches within that market. In fact, because munificence encourages more rivals to enter the market as slack resources help them to overcome entry barriers, firms are motivated to differentiate their product offerings from competitors. In addition, some (or many) of the rivals may enter via their own innovative products increasing the pressure on incumbent firms to innovate and/or further differentiate their products. Differentiation is likely to be an important source of competitive advantage in such industries (Hitt, et al., 2020). Therefore, the strategy to create new market opportunities is used by more firms when they operate in a munificent environment.

Hypothesis 3b: Industry munificence is positively related to the use of an entrepreneurial strategy.

\section{METHOD}

\subsection{Country institutional contexts}

We collected data from three continents, Asia, Europe, and North America, in order to capture variance in institutional environments. Specifically, we selected our sample firms from China, the U.S., and European countries because they exhibit different formal institutional environments. In support, Holmes et al. (2013) found China, the U.S., and western European firms to have institutional environments composed of distinct economic, political, and regulatory institutions. And, this sample of countries includes both developed (i.e., the U.S. and Western EU 
countries) and emerging economies (i.e., China and Eastern EU countries-Bulgaria and Romania are on the cusp between developing and emerging economies). The institutional settings in these countries provide a suitable context to examine the research questions regarding the influence of country level formal institutions and industry attributes on firm-level behavior.

\subsection{Sample and data}

Collecting primary data from firms based in several countries presents challenges to maintain methodological and sampling balance and obtain comparable data from firms having the desired characteristics (Cumming et al., 2009). Given the theoretical framework, we needed variance in the country-level formal institutions along with a sample of firms operating in varied industries. We selected sample firms from a crosssection of industries from the three continents identified. Below, we explain our sample and procedures in each. The process of selecting the samples and procedures used in data collection necessarily varied in some ways across the three continents based on the requirements for collecting such data in each.

3.2.1 Asia-China. China is a large diverse country with considerable variance in industries across regions. As such, we identified 5000 representative firms from a variety of industries across six provinces (Shaanxi, Henan, Guangdong, Jilin, Jiangsu, and Shandong which represent eastern, central and western China) and a broad scope of firm sizes. These were identified in consultation with provincial government officials who had records on all of the companies operating in their region. We then randomly selected 800 of these firms to contact about participating in the study. Members of the research team and provincial government officials cooperated to contact the top executives, largely by telephone, to gain their agreement to participate. Executives at 750 firms agreed to participate in the survey. Respondents to this survey were top executives (e.g., CEOs, COOs, or other senior executives). We obtained data from 616 enterprises using structured interviews (the survey instrument described later provided the structure for the interviews). ${ }^{2}$ There were 12 interviewers, Ph.D. candidates with training in research methodology, chosen based on their knowledge of survey research. In addition, a training course was conducted for the interviewers to ensure reliable responses. The training communicated the general objectives of the study, the appropriate means of responding to managers' questions and how to clarify any confusion experienced by the managers.

\footnotetext{
${ }^{2}$ This represents an $82 \%$ response rate based on the 750 firms in which the executives agreed to participate. If we consider the 800 randomly selected firms as the universe, the response rate would be $77 \%$. Both are excellent.
} 
To enhance the construct validity of the measures and data, two executives per firm, commonly the CEO and COO, were asked to complete the survey (Podsakoff and Organ, 1986). The survey was administered in teams composed of two interviewers and the respondent. Importantly, the interviewers interviewed the CEO and COO separately. After both questionnaires were complete, the interviewers compared the two sets of answers and asked for clarification and additional information if there were distinct differences between the two answers to the same question in the company. For our purposes, the two responses per firm per variable were averaged for use in our study.

3.2.2 North America-U.S. The U.S. is also a large country in which executives have been inundated with surveys. As such, many firms have instituted policies against completing surveys. Therefore, we had to identify a means of obtaining survey data from top executives of firms representing a good cross-section of industries. We chose to survey graduates of a top-ranked executive MBA program at a major U.S. university. Graduates of this program have an average of 18 years of experience when they entered the program and were middle managers or top executives at the time. We chose this program because almost all the graduates hold top executive positions and their firms represent a broad spectrum of industries (e.g., high technology, financial services, healthcare, energy, manufacturing, etc.). We selected the 360 graduates from the period of 2001-2007 to survey (to increase the probability they held a high-level management position). There was contact information available on 348 of them. A letter of support for the study was sent to the graduates by the top administrator of this program and all communications were handled through the EMBA office. The researchers sent a letter explaining the study to each graduate with a link to an electronic survey which when completed was forwarded directly to the researchers. We received responses from 126 participants. $^{3}$

3.2.3 European countries. Sample selection in Europe was a challenge. We needed data on firms from multiple countries, representing a variety of industries and from major executives knowledgeable of the overall firm operations and strategies. And, we needed satisfactory response rates. Thus, we used the graduates of a major business school in the U.K. as the sampling frame because they met the criteria noted above. This business school has more than 30,000 graduates so we selected a random sample of 1,800 from this group. We also included 300 graduates from a special business program offered by this school in a major metropolitan area because of the heavy concentration of managers in the program. Current contact information was available for 1,913 members of this

${ }^{3}$ This represents a $36 \%$ response rate which is considered to be good when surveying top executives in the U.S. 
group. They were contacted by the top program administrator asking for their participation in the electronic survey.

Follow-up requests were sent several weeks after the initial contact. Completed surveys were received from 223

participants. $^{4}$

Thus, we received 965 responses from a total of 3,011 who were contacted for an overall response rate of 32 percent. This is an especially positive rate of response given the complex nature of the study and information obtained from top executives of the firms studied (see Tootelian and Gaedeke, 1987, for information on survey response rates). We obtained data on the level of the respondent below the CEO. Most of the respondents were CEOs or reported to the CEO (member of the top management team). Qualitative assessments were made for interviewees who were several levels below the CEO to determine if they were likely knowledgeable of their firm's strategy and the major external relationships. We were guided by the recent research noting that middle managers play a key role in the implementation of the firm's strategy (Greer, Lusch and Hitt, 2017; Hitt, Jackson, Carmona, Bierman, Shalley and Wright, 2017). Because of missing data and a few respondents whose knowledge of the firm's strategy was judged to be uncertain, the number of usable responses, each representing a different firm, was 828 . As described later, we had institutional data on 50 countries. We received responses from firms based in a few small European countries (e.g., developing countries Croatia, Kosovo and Serbia) for which full institutional and/or industry data were unavailable. These firms were excluded from this study. In addition, we examined the industries across the whole sample and were able to identify 13 shared industries which had reasonable representation in the sample and/or were especially important for the country/region. The distribution of industries across China, Europe and the U.S. is shown in Table 1. As depicted in the table, the sample in each grouping was composed of firms in 10-12 of the 13 industries. While the distributions are indicative of the most important industries in each country/region, manufacturing composed the largest set of firms in all three regions. Firms in other industries (e.g., unable to identify the primary industry of the firm) were excluded from the sample. Thus, the total usable sample for this study is 658 firms, providing strong statistical power. The resulting sample represented firms based in 17

\footnotetext{
${ }^{4}$ This represents a $12 \%$ response rate which is normally considered to be marginal. However, participating firms represented a wide variety of industries and 15 different European countries (along with other developing countries which could not be included in the analyses because of lack of quality data on formal institutions and/or industry attributes). Also as noted, our tests for non-response bias supported the representativeness of the sample. The number of respondents from each of the countries included in our final sample are as follows: Austria-3. Bulgaria-9, Denmark9, Finland-2, France-3, Germany-6, Greece-4, Hungary-1, Ireland-8, Italy-4, Netherlands-4, Romania-33, Sweden-2, Switzerland-3, U.K.-67,
} 
countries: Austria, Bulgaria, China, Denmark, Finland, France, Germany, Greece, Hungary, Ireland, Italy,

Netherlands, Romania, Sweden, Switzerland, U.K., and the U.S.

\section{Insert Table 1 about here}

Next, we examined the potential for non-response bias, in slightly different ways in each country due to data availability and sampling requirements (Lambert and Harrington, 1990). In China, we compared the responding and non-responding firms on major attributes including firm size, ownership status, sales, and age; all t-values were statistically insignificant suggesting no differences between responding and non-responding firms. In the U.S., we compared the responding and nonresponding firms based on their industry and their size, finding no statistically significant differences. Finally, in the European sample, we compared early and late responders on the primary variables from the survey and found no statistically significant differences. These results suggest no problem with non-response bias. Based on these data, broad set of industries and the large number of countries, we concluded that we had a reasonably representative sample.

\subsection{Survey instrument}

While data on several of the key variables were gathered from archival sources, a survey instrument was developed to measure the dependent, moderator and some control variables for which secondary sources were unavailable. To develop the items for each construct, a thorough review of the literature was conducted. Some measures had been previously used and we adopted those items, while in other cases, items had to be developed. We designed items for each construct in English and pilot tested with two classes of advanced graduate students. Thereafter, the number of items was pared down and several items revised. The revised English instrument was reviewed with several managers for consistency, clarity, and uniformity. This feedback required a few minor revisions with special sensitivity to the length of the instrument.

The instrument was then translated into Chinese after which the questionnaire was separately backtranslated by two additional scholars to ensure the consistency of the English and Chinese versions. A pilot test was then conducted with 18 Chinese managers, in which each item was checked with pilot test participants to ensure that it could be accurately understood. Based on the feedback, minor modifications were made to ensure understanding by the Chinese managers. This modified version was checked by a native-English-speaking professional who is also fluent in Chinese to ensure that the modifications did not change the original intent of the English version. This version was reviewed by three other executives and some minor modifications were made based on their 
suggestions. The modified version was reviewed by an American professor of Chinese descent for the accuracy of the translation. The final version of the instrument was used to collect data from the Chinese, European and U.S. executives. Thus, the same survey instrument was used in all countries.

\subsection{Independent variables}

The measures for the three independent variables-institutions, industry dynamism, and industry

munificence-were constructed from secondary data.

3.4.1 Institutions. Data on formal institutions were obtained by gathering information on country-level political, regulatory, and economic environments. We used the factors created by Holmes et al. (2013). They collected data on a large number of variables from Freedom House, Index of Economic Freedom, POLCON, Political Risk Factors, and World Bank’s World Development Indicators to measure the country's economic, political, and regulatory institutions. They then conducted an exploratory factor analysis of the institutional variables reducing the set to 20 variables, which loaded on four factors-political democracy, regulatory control, capital availability, and market liquidity. Political democracy reflects the means through which government officials and other individuals enact changes in formal institutions. Regulatory institutions establish and enforce laws and policies that govern business activities. Capital availability influences firms' investment decisions through access to capital and its value. Market liquidity captures a country's liabilities, exchange rate, and liquidity. Both of the economic institutions variables are largely controlled/influenced by government policies (e.g., regarding interest rates) and actions (e.g., changes in the supply of money). For both the political and economic institutions, high scores suggest strong institutions. They are also more efficient; for example, low scores on the economic institutions suggest fewer policies designed to manage the variability in economic growth thereby producing a more chaotic economic system. The regulatory institution variable stands in contrast. Although some legal and regulatory protections are desirable for managers, overly bureaucratic rules and procedures can be onerous and time consuming to ensure adherence, hence highly inefficient. In effect, such rules and policies greatly increase the transaction costs and opportunity costs for managers. So, high scores suggest a significant bureaucratic regulatory system which is very inefficient.

Therefore, this variable was reverse scored for integration with the other institutional factors (the reverse scored regulatory control factor was highly and positively correlated with each of the other institutional factors thereby supporting this approach). The latent variable, Institutions, was then created using the factors, in which capital availability (0.61), market liquidity (0.98), political democracy (0.95), and regulatory control (0.95) load positively 
in the partial least squares (PLS) models that were used to test the hypotheses (as described below). This measure captures complex institutions (integrated effect of multiple institutions).

3.4.2 Industry attributes. Scholars have argued that industry dynamism and munificence are critical environmental attributes that have important effects on firms' behaviors (e.g., Baum and Walley, 2003; Bradley et al., 2011; Garg et al., 2003; Keats and Hitt, 1988). Therefore, we developed measures of industry dynamism and munificence.

We collected industry-revenue data over five years for the 13 different industries within each country. These data were collected from archival sources including Compustat for the US, Statistical Yearbook for the Chinese, and Euro Stat and European Business and BVD databases for the European firms. With these data, we then calculated industry Dynamism and Munificence following the regression-based procedure used by Keats and Hitt (1988). The indicators for Munificence were five-year average growth in net sales and growth in operating income in the dominant industry. Using annual figures for all firms in each industry, we calculated natural logarithms of each in a time series approach (time was the independent variable). The growth measure of each was the antilog of the regression slope coefficient resulting in a smoothed measure of the average growth rate. The basic equation for these indicators is given by

$$
\begin{aligned}
& y_{t}=b_{0}+b_{1} t+a_{b} \\
& \text { where } \\
& \mathrm{y}=\text { industry sales or industry operating income, } \\
& \mathrm{t}=\text { year, and } \\
& \mathrm{a}=\text { residual }
\end{aligned}
$$

The indicators for Dynamism reflect five-year patterns in the industry. The measures were the antilog of the standard error of each regression slope coefficient from the growth equations described above.

Additionally, we have perceptual measures of the same two constructs (data collected in the survey). The perceptual measures are positively and highly correlated with the objective measures providing evidence of construct validity for our archival measures.

\subsection{Dependent variables}

The dependent variables are two strategies, capability advantage strategy and entrepreneurial strategy. They were measured using primary data obtained from the survey instrument. The capability advantage strategy, as 
described previously, increases market share or geographic scope via a distinctive advantage providing superior value to customers (four items on 5-point Likert-type scale). Specifically, the respondents were asked to evaluate the extent to which their firm used a strategy that: 1) Highlights our vastly superior sets of capabilities; 2) Focuses on exploiting our distinct capability advantages; 3) Lets our strongest capabilities drive our competitive actions; and 4) Uses our capabilities to create competitive advantage in the existing market. The entrepreneurial strategy utilizes the firm's resources and capabilities to create new market opportunities for the firm to exploit and thereby offer superior value to customers (three items on 5-point Likert-type scales). Specifically, the respondents were asked about the extent to which their firm used a strategy that: 1) Highlights our commitment to producing new products/services; 2) Focuses on creating new products/services and/or new markets; and 3) Lets the creation of new markets and/or new products drive our competitive actions. The factor analysis results indicated high loadings per item for each strategy construct. Specifically, all items showed high and positive loadings in the PLS models-Capability Advantage $(0.79,0.81,0.83,0.88)$ and Entrepreneurial $(0.89,0.90,0.81)$. And importantly, no meaningful cross loadings were present. Moreover, each of the measures had high coefficient alpha scores-Capability Advantage with 0.86 and Entrepreneurial with 0.83 .

\subsection{Moderator variable}

The theoretical arguments and model suggest that Relational Capital moderates the relationship between dynamism and firm strategy. Relational Capital was measured based on the instrument utilized by Atuahene-Gima and $\mathrm{Li}$ (2004) to capture the relationship with key stakeholders (on a five-point Likert type scale) including financial firms (sample item: We have developed close connections with officials of financial institutions), suppliers (sample item: We have invested in relationships with the managers of our suppliers) and government agencies (sample item: We ensure good relationships with influential government officials). These relationships have been shown to affect multiple types of resources available to firms (Sirmon et al., 2007). The coefficient alpha scores for these three dimensions of relational capital are 0.91, 0.92, and 0.87 respectively. A composite variable was created in the PLS model with positive loadings for financial firms (0.38), suppliers (0.96), and government agencies $(0.44) .^{5}$

\footnotetext{
${ }^{5}$ The only variables in our theoretical model that were from the survey and thus subject to potential common method bias were the two types of strategies and relational capital. The amount of shared variance between relational capital and the two strategy variables was low (12\% and $16 \%$ respectively). Additionally, all items for each of the variables loaded highly on the appropriate variable and there were no cross loadings. Lastly, the theoretical relationship between relational capital and firm strategies was configural (with industry dynamism) making it highly unlikely for the relationship to be affected by common method bias (Podsakoff et al., 2003).
} 


\subsection{Control variables}

We used six general control variables including firm Performance, Size, firm Age, Risk Aversion, Slack, and Synchronization. Firm Performance was used in the PLS model as an 'ultimate dependent variable'. It was measured via two scales each with three survey items derived from instruments used by Douglas and Judge (2001) and Garg, Walters, and Priem (2003). The two scales captured financial performance and performance quality relative to competitors which together better reflect competitive advantage than an absolute measure of financial performance alone. The items for financial performance were sales growth, return on assets, and return on sales relative to competitors over the past 3 years. The items for performance quality were customer satisfaction, quality of the products and product/service innovation relative to competitors over the past 3 years. Based on a factor analysis, each set of items converged on a single construct with high coefficient alphas of 0.89 and 0.78 , respectively. The latent variable, Performance, was then created using the factors, in which financial performance $(0.85)$ and performance quality (0.83) load positively in the PLS models. We obtained objective performance data, return on sales (ROS), for 140 of the firms across the three regions of our sample (in which archival data were available). The correlation between ROS and the survey measures is positive and statistically significant, thereby providing support for the validity of the performance measure.

Firm Size was measured as the total number of employees in the firm. It was used as a control because studies have shown that it can influence firm activities and performance (Baum and Wally, 2003; Josefy et al., 2015). Firm Age was measured as the number of years since the formation of the firm. Firms often go through life cycles where they grow early and then reach a mature stage in which the firm becomes inertial and performance levels off. Risk Aversion was controlled because the two strategies likely vary based on the risk propensity of the firm's managers as well as the performance of the firm (Bromiley, 1991). Risk aversion was measured with an instrument modified from Steensma and Corley (2001); its alpha score was 0.70 . We controlled for Slack as it can influence the strategy chosen as well as its success. Specifically, two different forms of slack, financial, and operational, were measured with instruments modified from Tan and Peng (2003). The coefficient alpha scores for these two variables were 0.85 and 0.71 , respectively. These two components were integrated into a composite variable in the PLS model with loadings of 0.96 and 0.54 , respectively. In addition, because synchronization is important for implementation of the strategies (Sirmon et al., 2007), we included a path from synchronization to each of the strategies in the models. Synchronization is critical because it involves the managerial activities to 
coordinate and integrate the resource investment decisions, bundling the resources to create capabilities and leveraging those capabilities to implement the firm's strategy (Sirmon and Hitt, 2009) (four items on 5-point Likerttype scale). Specifically, the firm respondents were asked to evaluate the extent to which: 1) Our firm invests a significant effort to link the structuring, bundling, and leveraging processes; 2) Significant communications occur between managers in our firm who influence the structuring, bundling, and leveraging actions; 3) Managers seek feedback to better integrate our firm's structuring, bundling, and leveraging actions; and 4) Top management actively participates in the firm's structuring, bundling, and leveraging actions. The items were used to create a composite measure of Synchronization with all items showing high and positive loadings in the PLS models $(0.84$, $0.89,0.86,0.82)$ and the scale had a coefficient alpha of 0.88 .

\subsection{Data structure and analysis}

Data on the formal institutions and industries were collected over a period of years to ensure they accurately represented the constructs measured (smoothing any potential anomalous years). Data for the formal institutions were collected for the years 1995-2003. Data for the industry characteristics of dynamism and munificence were collected for the years of 2001-2005. To ensure a lag structure, the survey data were largely collected in 2007

We used Partial Least Squares (PLS) to analyze the data for hypotheses testing following successful use in prior research (Henseler, Ringle, and Sinkovics, 2009; Hulland, 1999). Although 17 countries represent a significant number from which to collect primary data, we cannot assume that our data on country-level institutions are distributed normally. Thus, we needed a sophisticated nonparametric analytical tool to analyze a complex theoretical model. In contrast to covariance-based structural equation modeling such as LISREL, PLS is a component-based structural equation modeling approach (Esposito Vinzi et al., 2010) that makes less stringent assumptions about the distribution of the variables and is able to estimate complex models with many latent and manifest variables (e.g., our institutions variable) (Chin, 2010; Hulland, 1999; Shamir, Zakay, and Popper, 1998). The results of PLS analyses are evaluated considering the composite reliability, average extracted variance, $\mathrm{R}$ square, and bootstrap for the t-values (Chin, 2010; Henseler et al., 2009; Hulland, 1999). We used SmartPLS software for the analyses (Ringle, Wende, and Will, 2005). 


\section{RESULTS}

The description for all variables in the study is presented in Table 2. We produced two PLS models because of their complexity and for ease of interpretation, one for each strategy; thus, we present two correlation matrices. The correlation matrices suggest no significant collinearity problems. Furthermore, although the two strategies are positively correlated, they share only slightly more than 14 percent common variance. Based on regression analyses, we find that VIF scores indicate no threat of multicollinearity. The mean VIFs in the two models are 2.50 and 2.48, well below the stringent 5.0 guideline recommended by some scholars (e.g., Kutner, Nachtsheim, and Neter, 2004).

\section{Insert Table 2 about here}

The convergent and discriminant analyses for the variables in each of the PLS models are presented in Appendix 1. These results provide strong support for the construct validity of all the theoretical variables with multiple items (Institutions, Capability Advantage Strategy, Entrepreneurial Strategy, and Relational Capital). The results of the hypotheses tests are presented in Table 3 with the results for all paths including the control variables.

\section{Insert Table 3 about here}

Hypothesis 1a suggests that national formal institutions are negatively related to dynamism within industries. Results in Table 3 (Models 1 and 2) show that Institutions has a negative effect on Dynamism $(b=-0.19$, $p=0.001$, in both models). These results provide support for Hypothesis 1a. Hypothesis $1 \mathrm{~b}$ states that national formal institutions are negatively related to munificence in the industry. Results in Table 3 (Models 1 and 2) show that Institutions has a negative effect on Munificence ( $b=-0.90, p=0.001$, in both models). These results provide support for Hypothesis $1 b$.

Hypothesis 2a states that dynamism in the industry is negatively related to the use of the capability advantage strategy. Results in Table 3 (Model 1) show that Dynamism has a marginally negative effect on the Capability Advantage Strategy ( $b=-0.06, p=0.090$ ). These results provide marginal (or directional) support for Hypothesis $2 \mathrm{a}$. Hypothesis $2 \mathrm{~b}$ suggests that dynamism in the industry is negatively related to the use of the entrepreneurial strategy. Results in Table 3 (Model 2) show that Dynamism has a negative effect on the Entrepreneurial Strategy $(b=-0.13, p=0.001)$. These results provide support for Hypothesis $2 \mathrm{~b}$. Hypothesis $2 \mathrm{c}$ states that relational capital is a positive moderator of the relationship between dynamism and capability advantage strategy. Results in Table 3 show that the interaction between Dynamism and Relational Capital has a positive effect on the Capability Advantage Strategy $(b=0.08, \mathrm{p}=0.025)$. The plot of this interaction in the Appendix 2 
shows that firms with high relational capital increasingly engage in the advantage-based strategy in more dynamic environments. These results provide support for Hypothesis 2c. Hypothesis 2d states that relational capital is a positive moderator of the relationship between dynamism and the entrepreneurial strategy. Results in Table 3 show that the interaction between Dynamism and Relational Capital has a positive effect on the Entrepreneurial Strategy ( $b=0.08, \mathrm{p}=0.042$ ). The plot of this interaction in the Appendix shows that firms with high relational capital increasingly engage in an entrepreneurial strategy in more dynamic environments. These results provide support for Hypothesis $2 \mathrm{~d}$.

Hypothesis 3a states that munificence in the industry is negatively related to the use of the capability advantage strategy. Results in Table 3 (Model 1) show that Munificence has a negative effect on the Capability Advantage Strategy $(b=-0.13, p=0.002)$. These results provide support for Hypothesis $3 a$. Hypothesis $3 b$ suggests that munificence in the industry is positively related to the use of the entrepreneurial strategy. Results in Table 3 (Model 2) show that Munificence has a positive effect on the Entrepreneurial Strategy $(b=0.17, p=0.001)$. These results provide support for Hypothesis $3 b$.

While not hypothesized, we included performance in the empirical model to examine the relationship of the two strategy variables with firm performance. Results in Table 3 (Model 1) show that the Capability Advantage Strategy has a positive effect on Performance $(b=0.33, p=0.001)$. The results in Table 3 (Model 2) also show that the Entrepreneurial Strategy has a positive effect on Performance $(b=0.23, p=0.001)$. These results support our expectations.

\subsection{Endogeneity tests}

Endogeneity may result in biased statistical results (Greene, 2012). There are three potential sources of endogeneity: omitted variables, simultaneity, and measurement error (Antonakis et al., 2014). Because we used PLS for the analyses, the latent variables were measured by multiple indicators helping to avoid endogeneity due to measurement error. However, we risk problems caused by omitted variables and simultaneity. Therefore, we used a two stage least squares (2SLS) estimation. The exogenous variable in the models is institutions which can be a potential source of endogeneity. Therefore, we analyzed our data with all variables, including an instrumental variable: country infrastructure development (Antonakis, et al., 2014). We used infrastructure development as an instrumental variable because it was remotely related to other endogenous variables (the mean absolute correlation coefficient is 0.098 ), and it was highly correlated with the independent variable (the correlation coefficient between 
infrastructure development and institutions is 0.92) (Greene, 2012; Semadeni, Withers, and Certo, 2014). The direction, magnitude, and the significance of all relationships in the two models (capability advantage strategy and entrepreneurial opportunity strategy) were consistent with our original findings. Therefore, these results suggest that endogeneity was not a problem with our data.

\subsection{Robustness tests}

We also conducted several robustness tests. First, we inserted perceptual measures of dynamism and munificence in place of the objective measures used for the hypothesis tests. We then ran the same models with these measures and the results were substantively equivalent (same direction and levels of statistical significance) to the models with the objective measures. These results are particularly important because the perceptual measures may capture the industry norms as perceived by managers and on which they base their strategic decisions.

Second, we developed several models in which we included a direct path from institutions to the strategies and other variables (e.g., some control variables such as synchronization). These paths were statistically significant when the paths from industry dynamism and munificence to the same variables were not in the model. However, when these theoretically mandated paths were added to the model (as in the final models shown herein), the coefficients for the effects of institutions on the strategies became insignificant. ${ }^{6}$ These results suggest that the effects of national formal institutions are indirect and through the key industry attributes of dynamism and munificence.

Prior research has found that executive characteristics may influence the strategic choices that they make (c.f., Hambrick, 2007). For our purposes, the executives' tenure with the company might affect the strategies they employ assuming that they are influenced by past company practices or other industry norms. Thus, we developed models which included the amount of time the executive had been employed by the firm as a control variable. In these models, the path between executive Tenure and Capability Advantage Strategy was statistically insignificant $(\mathrm{b}=-0.01$, n.s. $)$ as was the path with Entrepreneurial Strategy $(\mathrm{b}=-0.049$, n.s. $)$. Importantly, all results of the hypotheses tests remain substantively the same (same direction and levels of statistical significance).

\footnotetext{
${ }^{6}$ The direct effect of institutions on capability advantage strategy $(b=-0.010, n . s$. $)$ and entrepreneurial strategy $(b=-$ 0.004, n.s.) are not statistically significant when industry dynamism is included in the model. Similarly, the direct effect of institutions on capability advantage strategy $(b=-0.019, n . s$. $)$ and entrepreneurial strategy $(b=0.066, n . s$. $)$ are not statistically significant when industry munificence is included in the model.
} 
Lastly, because the sample sizes are imbalanced across countries/regions, we analyzed the data without the largest subsample (China). Thus, the analyses included all firms from European countries and the U.S. The results of all the hypotheses tests remained the same except the level of statistical significance of the relationship between munificence and the capability advantage strategy changing from $p=0.002$ to $p=0.13$. The direction was the same so the small change in significance could be due to lower statistical power with the smaller sample size. Overall, we conclude that these results show robust support for the results.

\section{DISCUSSION}

The intent of this research was to expand our understanding of how previously overlooked complexities in a firm's environmental context affects its choice between an entrepreneurial strategy versus one that defends a current advantage (Ireland, Hitt, and Sirmon, 2003). However, that context is not isolated to the national-institutional or industry level. Instead, we argued herein that the environmental context is a complex, nested arrangement among these different levels that influences the firm's choice of strategy.

In dynamic industries we found firms to be less inclined to choose either an entrepreneurial or defensive strategy to protect their current advantages. However, the negative effect was stronger for entrepreneurial strategies. Thus, in general, firms tend to become more conservative in dynamic environments with an even stronger tendency to abstain from entrepreneurial strategies. However, some firms break from this approach by building strong relationships with primary stakeholders to help them manage the uncertainty. Building strong relational capital with external stakeholders provides access to resources, financial, social, and informational, that in turn help them to manage the uncertainty and resist a conservative response. Given the aversion to employing entrepreneurial strategies in highly dynamic environments, the effect of relational capital on engaging entrepreneurial strategies is pronounced. Using these strategies help them to identify and exploit market opportunities that especially exist in these highly dynamic environments. Thus, building and maintaining effective relationships with their primary stakeholders can help the firm to exploit new opportunities. They may even disrupt the market with their entrepreneurial strategy and create a significant new competitive advantage.

Next, munificent environments produced even stronger differences. Here firms are less likely to engage in a capability advantage strategy and more likely to engage in an entrepreneurial strategy. It is perhaps natural to assume that a more munificent environment has a positive influence on firms. On the surface, this assumption seems logical because firms have access to a greater amount of resources. However, such environments reduce the barriers 
for entry into the industry and specific markets and niches within it (or provide the resources which can be used to overcome existing barriers), thereby enhancing the amount of competition and competitive rivalry (competing for market share). In munificent environments, current advantages are more easily imitated, and competitors can more readily reduce their competitive disadvantages (because of the availability of resources to do so) (Sirmon et al., 2010). As a result, firms are less likely to pursue a capability advantage strategy. Rather, they need to take actions that differentiate the value they provide to customers and choose a strategy to create new market opportunities.

However, as our theory suggests, the effect of environment on strategic choice is not shown by industry attributes alone. Strong national institutions constrain both dynamism and munificence. Thus, in line with our theoretical expectations, results show that effects of formal national institutions and industry attributes together affect firm strategies, yet in more nuanced ways than previously known. We found that the influence of complex institutions on the strategic behavior of firms is indirect via industry attributes (see robustness tests). More specifically, while some prior research has shown the effects of specific institutions on particular strategies (e.g., Brouthers, 2002; Henisz, 2002), this study suggests that institutional effects are more complex (e.g., Batjargal et al., 2013; Ostrom, 2005, 2010). Country-level institutions are pluralistic and sets of institutions 'co-govern' thereby having a combined influence (complex and integrated). That is, the executives formulating strategies do not consider only the influence of a single formal institution; rather, they consider multiple important and influential institutions in combination when formulating the firm's strategy. But this influence is indirect as they primarily focus on conditions within the industry.

Thus, firms' strategic actions are primarily shaped by industry attributes (reflecting behavior often related to the rivals' commutative competitive actions). That is industry attributes, due to their closer proximity to decision makers, are more directly influential for the strategic behavior of firms. Our findings suggest that previous research may suffer from mis-specified models when examining direct links between institutions and firm strategies. As a result, our research extends prior work and provides more specificity on the joint institutional influence. Indeed, our theory and empirical results support the notion that combinative institutional effects indirectly influence firm strategies.

More specifically this research found that national formal institutions place boundaries (constraints) on the industry environment. When the formal institutions at the national level were stronger and more efficient, the dynamism in the industry and the resources available in the environment (munificence) were lower. Therefore, 
strong and efficient national institutions contribute to more stable industry environments. However, this same national institutional environment bounds the amount (and perhaps the type) of resources available to firms for use in implementing their strategies (e.g., pursuing entrepreneurial opportunities). Thus, while there likely will be a smaller number of rivals (fewer new entrants thereby contributing to more stability in the industry), the relationship among the firms may be more competitive to access the limited resources. As a result, the influence of country-level formal institutions is intricate having both positive and perhaps negative effects. Additionally, this research explains part of the reasons industry influence varies. Perhaps, it also helps us better understand why McGahan and Porter (1997) found firm profitability to vary considerably across industries.

The dynamism in the industry environment and its munificence, in turn, affect the industry practices managers need to follow in order to succeed (and at the extreme to survive). The industry practices are based on industry recipes which are norms for behavior (Spender, 1989) required to achieve legitimacy. Thus, our research suggests that firms must respond to a complex set of formal and informal rules in order to succeed in their competitive landscape (Hitt et al., 1998). The rules emerge from the national institutional environment and influence the attributes of the industry environment and the expected practices within each industry. These 'rules of the game' provide the logic managers can use to implement strategies that gain a competitive advantage over their industry rivals.

Importantly, our research provides a more nuanced understanding of the negative effects of dynamism on the use of an entrepreneurial strategy. First, our main effects results help us understand why some (many) firms are less innovative and less venturesome in uncertain environments. In such environments, some argue that firms need to be more rather than less innovative in order to gain and sustain a competitive advantage (e.g., Hitt et al., 1998). Yet, perhaps the industry leaders tend to become more conservative in these environments (Keats and Hitt, 1988). Although a dynamic environment with significant uncertainty provides the potential to gain a unique advantage over rivals through innovation, the risks are high. It is quite challenging to continuously identify and successfully introduce to the market a new product or to identify and effectively serve a new market (creating demand where none existed previously). And, industry leaders often try to protect their current advantage(s) (Shimizu, 2007). It is common for firms to imitate the behaviors of industry leaders. Further, dynamism is characterized by uncertainty and turbulence in market and industry conditions. In an uncertain and turbulent environment (Dess and Beard, 1984; Sharfman and Dean, 1991), imitation of successful firms in the industry not only reduces search costs, but also helps 
firms achieve legitimacy (Haveman, 1993). Thus, because of the high risk involved with an entrepreneurial strategy and the requirements for its successful implementation in a highly dynamic environment, some managers are reluctant to implement this strategy in such environments.

Alternatively, if industry leaders try to maintain their current advantage with little change, it creates an opportunity for others to be entrepreneurial and to gain market share from them. However, our research suggests that firms building strong relational capital with important stakeholders are better able to engage in an entrepreneurial strategy in dynamic industry environments. With access to more resources, they can better manage the risk which in turn reduces their uncertainty; these conditions increase their willingness to search for and exploit new market opportunities. This is an important finding, as logic suggests that firms are unlikely to be successful over time in dynamic environments unless they are entrepreneurial. Our research shows that firms naturally become more conservative in environments with high uncertainty, but they can manage this uncertainty with strong relational capital and are more likely to be successful when they do.

Our research demonstrates the positive attributes of relational capital. Strong relationships typically build trust among the partners, enhance information flows between them and promote joint problem solving thereby leading to more effective solutions. Yet, highly embedded relationships also can have negative effects. For example, firms in such relationships rarely seek additional information and other resources outside of these relationships thereby bounding or constraining their learning opportunities which in turn contributes to organizational inertia. Such inertia may cause firms to become more conservative (less entrepreneurial) over time and may harm firms' ability to foresee major changes in their market (e.g., market disruptions). Thus, firms need to build strong relational capital with stakeholders while simultaneously remaining open to new and potentially fruitful relationships with other valuable stakeholders.

This study investigates the complexities that likely exist in institutional environments and as such is also complex. The theoretical model required an intricate and multifaceted research design. We had to gather primary data from firms across multiple institutional and industry environments. Although we accomplished this by collecting data from more than 650 firms in 17 countries located on three continents, such complex designs also present limitations. One of the largest challenges in such a design, outside of obtaining quality data from many firms, is to ensure comparability across countries. We took several actions to ensure comparability of the data gathered from firms (e.g., pilot studies and care in translating the survey) and on industries (e.g., using the same 
industry categories) across different countries. We also used national institutional measures shown to have construct validity (Holmes et al., 2013). But such actions do not guarantee perfect congruence.

Concomitant to the congruence concern, sampling requirements necessitated the selection of convenience samples in two regions. The sources for the samples were carefully chosen to ensure representation of a broad set of industries and a variety of countries (in the European sample), along with access to high-level managers. Yet, we cannot be assured that these samples are fully representative of the firms in their respective environments.

Hopefully, future research can identify ways to build samples in these regions that ensure representativeness and replicate the research reported herein to compare with the results.

Additionally, institutional complexity is a rather multifaceted theoretical construct and we were able only to capture a portion of it. Yet, this study provides the basis for future research on this construct. For example, future research could examine the effects of multilevel institutions. Such a study might involve both national and local institutions (e.g., provincial/state, municipal) to examine the interrelationships between the different levels of institutions along with their independent and integrated effects on industry and on firm strategies. The influence of informal institutions such as country and local culture could also be examined in the theoretical model tested.

Future research could examine the institutional influences on how resources are managed and allocated. For example, what are the formal institutional and industry influences on structuring the firm's resource portfolio and bundling the resources to create capabilities? Future research is needed to examine the temporal effects of resource management practices (e.g., when and how resources are invested in human capital and in R\&D projects) on competitive strategies (Bridoux, Smith, and Grimm, 2013). For example, research has shown that firms investing in acquiring human capital during economic downturns perform at higher levels when the economy turns around (Greer and Ireland, 1992). In what strategies do these firms with richer human capital engage to gain market share from rivals? Human capital resources may be particularly important in the implementation of entrepreneurial strategies (Greer et al., 2017). Thus, we need more research on the practices required to effectively implement entrepreneurial and advantage-based strategies. Alternatively, future research could examine different firm behaviors such as diversification, internationalization, alliance formation, etc., as important strategic behaviors for obtaining or sustaining a competitive advantage under different institutional and industry environments.

Finally, although we took great care in the development of our dataset, there are some potential limitations. First the data may not be considered contemporary. We have time series data that began in 1995 and end in 2007 (9 
years of institutions data, 5 years of industry data, and survey data collected in the period of 2005-2007). The years 2007 and 2008 were marked by a major global recession and recovery in many countries extended well beyond these years (perhaps through at least 2012). Thus, our years of data capture a more normal time for business. Institutions tend to change slowly as do most industries. Yet, future research should be conducted to ensure that the relationships discovered with our data remain applicable in the current time period.

Additionally, while we tried to take great care to ensure the survey respondents were likely knowledgeable of broader firm attributes and strategy, the level of respondents varied to a degree (from CEO to a few levels below the CEO). Therefore, future research is needed to examine the relationships in this study using information obtained from CEOs or at least limited to top management team members. Using such a sample will largely guarantee a knowledge of the firm's strategy and other major attributes (e.g., relations with major stakeholders and performance of the firm).

In conclusion, this study has provided empirical evidence of the complex nature of institutions and their influences on industries and firm strategies. It has provided a more nuanced understanding of the environmental conditions within which firms engage in entrepreneurial and more defensive advantage-based strategies. It is one of the first studies in strategic management to show how complex national institutions influence firm strategies; they do so through their influence on the industry attributes within which firms must compete. Therefore, this study extends our knowledge of complex interlinkages among institutions, industry environments, and firm strategies. It adds to our understanding of how firms must manage within their environmental milieu to gain and sustain a competitive advantage. 


\section{REFERENCES}

Acemoglu, D., Johnson, S., \& Robinson, J. (2005). The rise of Europe: Atlantic trade, institutional change, and economic growth. The American Economic Review, 95: 546-579.

Aguilera, R., Judge, W., \& Terjesen, S. (2018). Corporate governance deviance. Academy of Management Review, 43: 87-109.

Aldrich, H.E., \& Martinez, M. (2015). Why aren't entrepreneurs more creative? Conditions affecting creativity and innovation in entrepreneurial activity. In C. Shalley, M.A. Hitt \& J. Zhou. (Eds.), Oxford Handbook of Creativity, Innovation and Entrepreneurship: 445-456. New York: Oxford University Press.

Alessandri, T.M. \& Khan, R.H. (2006). Market performance and deviance from industry norms: (Mis)alignment of organizational risk and industry risk. Journal of Business Research, 59: 1105-1115.

Anderson, P. \& Tushman, M.L. (2001). Organizational environments and industry exit: The effects of uncertainty, munificence and complexity. Industrial and Corporate Change, 10: 675-711.

Andrews, R. \& Johansen, M. (2012). Organizational environments and performance: A linear or nonlinear relationship. Public Organization Review, 12: 175-189.

Antonakis, J., Bendahan, S., Jacquart, P., \& Lalive, R. (2014). Causality and endogeneity: Problems and solutions. In D.V. Day (Ed.), Oxford Handbook of Leadership and Organizations: 93-117. New York: Oxford University Press.

Arregle, J.L., Miller, T., Hitt, M.A., \& Beamish, P.W. (2013). Do regions matter? An integrated institutional and semiglobalization perspective on the internationalization of MNEs. Strategic Management Journal, 34: 910934.

Arregle, J.L., Miller, T., Hitt, M.A., \& Beamish, P.W. (2016). How does regional institutional complexity affect MNE internationalization? Journal of International Business Studies, 47: 697-722.

Atuahene-Gima, K., \& Li, H. (2004). Strategic decision comprehensiveness and new product development outcomes in new technology ventures. Academy of Management Journal, 47: 583-597.

Bamiatzi, V., Bozos, K., Cavusgil, T., \& Hult, G.T.M. (2016). Revisiting the firm, industry, and country effects on profitability under recessionary and expansion periods: A multilevel analysis. Strategic Management Journal, 37: 1448-1471.

Bansal, P. (2002). The corporate challenges of sustainable development. Academy of Management Perspectives, 16(2): 122-131.

Barney, J.B. (2001). Resource-based theories of competitive advantage: A ten-year retrospective on the resourcebased view. Journal of Management, 27: 643-650.

Barney, J.B., Ketchen, D.J. \& Wright, M. (2011). The future of resource-based theory: Revitalization of decline? Journal of Management, 37: 1298-1315.

Barro, R.J. (2013). Inflation and economic growth. Journal of Economics and Finance, 14: 85-109.

Batjargal, B., Hitt, M.A., Tsui, A.S., Arregle, J-L, Webb, J.W., \& Miller, T. (2013). Institutional polycentrism, entrepreneurs' social; networks and new venture growth. Academy of Management Journal, 56: 1025-1049.

Baum, J.R., \& Wally, S. (2003). Strategic decision speed and firm performance. Strategic Management Journal, 24: 1107-1129.

Bekaert, G., Harvey, C. R., \& Lundblad, C. 2005. Does financial liberalization spur growth? Journal of Financial Economics, 77: 3-55.

Benner, M.J., \& Tripsas, M. (2012). The influence of prior industry affiliation on framing in nascent industries: The evolution of digital cameras. Strategic Management Journal, 33: 277-302.

Berry, H., Guillén, M.F., \& Hendi, A.S. (2014). Is there convergence across countries? A spatial approach. Journal of International Business Studies, 45: 387-404.

Bradley, S.W., Shepherd, D.A., \& Wiklund, J. (2011). The importance of slack for organizations facing tough environments. Journal of Management Studies, 48: 1071-1097.

Bridoux, F., Smith, K.G., \& Grimm, C.M. (2013). The management of resources: Temporal effects of different types of actions on performance. Journal of Management, 39: 928-957.

Bromiley, P. 1991. Testing a causal model of corporate risk taking and performance. Academy of Management Journal, 34: 37-59.

Brouthers, K.D. (2002). Institutional, cultural and transaction cost influences on entry mode choice and performance. Journal of International Business Studies, 33: 203-221. 
Casper, S., Lehrer, M., \& Soskice, D. (1999). Can high-technology industries prosper in Germany? Institutional frameworks and the evolution of the German software and biotechnology industries. Industry and Innovation, 6: $5-24$.

Chan, C.M., Isobe, T., \& Makino, S. (2008). Which country matters? Institutional development and foreign affiliate performance. Strategic Management Journal, 29: 1179-1205.

Chang, S-J, \& Wu, B. (2014). Institutional barriers and industry dynamics. Strategic Management Journal, 35 : 1103-1123.

Chin, W. (2010). How to write up and report PLS analysis. In V. Espositi Vinzi, W.W. Chin, J. Henseler \& H. Wang (Eds.), Handbook of Partial Least Squares: 655-690. Springer: Berlin.

Clarysse, B., Bruneel, J., \& Wright, M. (2011). Explaining growth paths of young technology-based firms: Structuring resource portfolios in different competitive environments. Strategic Entrepreneurship Journal, 5: 137-157.

Cumming, D., Sapienza, H., Siegel, D., \& Wright, M. (2009). International entrepreneurship: Managerial and policy implications. Strategic Entrepreneurship Journal, 3: 283-296.

Cyert, R.M., \& March, J.G. (1963). A Behavioral Theory of the Firm. Englewood Cliffs, NJ: Prentice Hall.

Dacin, M.T., Oliver, C. \& Roy, J.-P. (2008). The legitimacy of strategic alliances: An institutional perspective. Strategic Management Journal, 28: 169-187.

Danneels, E. (2012). Second-order competences and Schumpeterian rents. Strategic Entrepreneurship Journal, 6 : 42-58.

Davis, J.P., Eisenhardt, K.M., \& Bingham, C.B. (2009). Optimal structure, market dynamism, and the strategy of simple rules. Administrative Science Quarterly, 54: 413-452.

Dess, G.G., Ireland, R.D. \& Hitt, M.A. (1990). Industry effects and strategic management research. Journal of Management, 16: 7-27.

Dess, G. G., Lumpkin, G. T., \& Covin, J. G. (1997). Entrepreneurial strategy making and firm performance: Tests of contingency and configurational models. Strategic Management Journal, 18: 677-695.

Dess, G.G., \& Beard, D.W. (1984). Dimensions of organizational tasks environments. Administrative Science Quarterly, 29: 52-73.

Dess, G.G., Ireland, R.D., \& Hitt, M.A. (1990). Industry effects and strategic management research. Journal of Management, 16: 7-27.

DiMaggio, P.J., \& Powell, W.W. (1983). The iron cage revisited: Institutional isomorphism and collective rationality in organizational fields. American Sociological Review, 48: 147-160.

Donaldson, L. (2001). The Contingency Theory of Organizations. Los Angeles, CA: Sage Publications.

Douglas, T.J., \& Judge, W.Q. (2001). Total quality management implementation and competitive advantage: The role of structural control and exploration. Academy of Management Journal, 44: 156-169.

Eisenhardt, K. (1989). Making fast strategic decisions in high-velocity environments. Academy of Management Journal, 32: 543-576.

Eriksson, G. (1984). Growth, entry and exit of firms. Scandinavian Journal of Economics, 86: 52-67.

Esposito Vinzi, V., Chin, W., Henseler, J., \& Wang, H. (2010). Perspectives on partial least squares. In V. Espositi Vinzi, W.W. Chin, J. Henseler, \& H. Wang (Eds.), Handbook of Partial Least Squares: 1-22. Berlin: Springer.

Feldman, M. P. (2014). The character of innovative places: Entrepreneurial strategy, economic development, and prosperity. Small Business Economics, 43: 9-20.

Fischer, S. 1993. The role of macroeconomic factors in growth. Journal of Monetary Economics, 32: 485-512.

Fitza, M. (2014). The use of variance decomposition in the investigation of CEO effects: How large must the CEO effect be to rule out chance? Strategic Management Journal, 35: 1835-1852.

Garg, V., Walters, B.A, \& Priem, R.L. (2003). Chief executive scanning emphases, environmental dynamism, and manufacturing firm performance. Strategic Management Journal, 24: 725-744.

Greene, W.H. (2012). Econometric analysis (7th ed.). Upper Saddle River, NJ: Prentice Hall.

Greenwood, R., Raynard, M., Kodeih, F., Micelotta, E.R., \& Lounsbury, M. (2011). Institutional complexity and organizational responses. Academy of Management Annals, 5: 317-371.

Greer, C.R., \& Ireland, T.C. (1992). Organizational and financial correlates of a "contrarian" human resource investment strategy. Academy of Management Journal, 35: 956-984.

Greer, C.R., Lusch, R., \& Hitt, M.A. (2017). A service perspective for human capital resources: A critical base for strategy implementation. Academy of Management Perspectives, 31: 137-158. 
Grover, D., Shreedhar, G., \& Zenghelis, D. (2016). The competitiveness impact of a UK carbon price: What do the data say? Policy paper, ESRC Centre for Climate Change Economics, UK, January.

Hambrick, D.C. (2007). Upper echelon theory: An update. Academy of Management Review, 32: $334-243$.

Haveman, H.A. (1993). Follow the leader: Mimetic isomorphism and entry into new markets. Administrative Science Quarterly, 38: 593-627.

Henisz, W.J. (2002). The institutional environment for infrastructure investment. Industrial and Corporate Change, 11: 355-389.

Henseler, J., Ringle, C.M., \& Sinkovics, R.R. (2009). The use of partial least squares path modeling in international marketing. Advances in International Marketing, 20: 277-319.

Hillman, A., \& Keim, G. (1995). International variation in the business-government interface: Institutional and organizational considerations. Academy of Management Review, 20: 193-214.

Hitt, M.A. (2016). International strategy and institutional environments, Cross Cultural \& Strategic Management, 23: 206-215.

Hitt, M.A., Bierman, L., Uhlenbruck, K. \& Shimizu, K. (2006). The importance of resources in the internationalization of professional service firms: The good, the bad and the ugly, Academy of Management Journal, 49: 1137-1157.

Hitt, M.A., Ireland, R.D., \& Hoskisson, R.E. (2020). Strategic Management: Competitiveness and Globalization. Boston, MA: Cengage Publishing Co.

Hitt, M.A., Ireland, R.D., Sirmon, D.G., \& Trahms, C.A. (2011). Strategic entrepreneurship: Creating value for individuals, organizations, and society. Academy of Management Perspectives, 25(2): 57-75.

Hitt, M.A., Jackson, S.E., Carmona, S., Bierman, L., Shalley, C.E. \& Wright, M. (2017). Oxford Handbook of Strategy Implementation. New York: Oxford University Press.

Hitt, M.A., Keats, B.W., \& DeMarie, S. (1998). Navigating in the New Competitive Landscape: Building strategic flexibility and competitive advantage in the 21 st century. Academy of Management Executive, 12(4): 22-42.

Hitt, M.A., \& Xu, K. (2019). Institutions and entrepreneurial strategies. Quarterly Journal of Management, 4(2): 114.

Hmieleski, K. \& Baron, R.A. (2008). Regulatory focus and new venture performance: A study of under conditions of risk versus uncertainty. Strategic Entrepreneurship Journal, 2: 285-299.

Holmes, R.M., Miller, T., Hitt, M.A., \& Salmador, M.P. (2013). The interrelationships among informal institutions, formal institutions, and inward foreign direct investment. Journal of Management, 39: 531-566.

Hormiga, E., Batista-Canino \& Sanchez-Medina, A. (2011). The impact of relational capital on the success of new business start-ups. Journal of Small Business Management, 49: 617-638.

Huang, M., Yen, G. \& Liu, T. (2014). Reexamining supply chain integration and the supplier's performance relationships under uncertainty. Supply Chain Management, 19: 64-78.

Hulland, J. (1999). Use of partial least squares (PLS) in strategic management research: A review of four recent studies. Strategic Management Journal, 20: 195-204.

Ireland, R.D., Hitt, M.A., \& Sirmon, D.G. (2003). Strategic entrepreneurship: The construct and its dimensions. Journal of Management, 29: 963-989.

Jain, T., Aguilera, R., \& Jamali, D. (2017). Corporate stakeholder orientation in an emerging country context: A longitudinal cross industry analysis. Journal of Business Ethics, 143: 701-719.

Jose, M.L., Nichols, L.M. \& Stevens, J.L. (1986). Contributions of diversification, promotion and r\&d to the value of multiproduct firms: A Tobin's q approach. Financial Management, 15: 33-42.

Josefy, M., Kuban, S., Ireland, R.D., Hitt, M.A. (2015). All things great and small: Organizational size, boundaries of the firm and a changing environment. Academy of Management Annals, 9: 715-802.

Keats, B.W., \& Hitt, M.A. (1988). A causal model of linkages among environmental dimensions, macro organizational characteristics, and performance. Academy of Management Journal, 31: 570-598.

Kuratko, D.F. (2015). Corporate entrepreneurship: Accelerating creativity and innovation in organizations, in C.E. Shalley, M.A. Hitt and J. Zhou (Eds.) The Oxford Handbook of Creativity, Innovation and Entrepreneurship. Oxford University Press: New York, NY.

Kuratko, D.F. (2009). The entrepreneurial imperative of the 21st century. Business Horizons, 52: 421-428.

Kutner, M.H., Nachtsheim, C.J., \& Neter, J. (2004). Applied Linear Regression Models (4th ed.). New York, NY: McGraw-Hill Irwin.

Lambert, D.M., \& Harrington, T.C. (1990). Measuring nonresponse bias in customer service mail surveys. Journal of Business Logistics, 11: 5-25. 
Le Cottier, A. \& Santalo, J. (2017). The impact of parent firms' market munificence on MNCs' subsidiaries performance. Academy of Management Proceedings, https://doi.org/10.5465/ambpp.2014.252.

Levine, R., \& Zervos, S. (1998). Stock markets, banks, and economic growth. American Economic Review, 88 537-558.

Levitas, E., \& McFadyen, M.A. (2009). Managing liquidity in research-intensive firms: Signaling and cash flow effects of patents and alliance activities. Strategic Management Journal, 30: 659-678.

Li, Z. (2010). Equity market liberalization: Industry growth and the cost of capital. Journal of Economic Development, 35: 103-121.

Lu, Y., Zhou, L., Bruton, G., \& Li, W. (2010). Capabilities as a mediator linking resources and the international performance of entrepreneurial firms in an emerging economy. Journal of International Business Studies, 41: 419-436.

Lucas, R. E. (2003). Macroeconomic priorities. American Economic Review, 93: 1-14.

Mahnke, V., Venzin, M. \& Zahra, S.A. (2007). Governing entrepreneurial opportunity recognition in MNEs: Aligning interests and cognition under uncertainty. Journal of Management Studies, 44: 1278-1298.

March, J.G. \& Olsen, J.P. (1983). The new institutionalism: Organizational factors in political life. American Political Science Review, 78: 734-749.

McGahan, A.M., \& Porter, M.E. (1997). How much does industry matter, really? Strategic Management Journal, 18: $15-30$.

McGahan, A.M., \& Victer, R. (2010). How much does home country matter to corporate profitability? Journal of International Business Studies, 41: 142-165.

McGinnis, M. (2011). An introduction to IAD and the language of the Ostrom workshop: A simple guide to a complex framework. The Policy Studies Journal, 39: 169-183.

McGrath, R.G. \& MacMillan, I. (2000). The entrepreneurial mindset. Boston, MA: Harvard Business School Press.

McKinley, W., Latham, S., \& Braun, M. (2014). Organizational decline and innovation: Turnarounds and downward spirals. Academy of Management Review, 39: 88-110.

Meyer, K.E., Estrin, S., Bhaumik, S.K., \& Peng, M.W. (2009). Institutions, resources, and entry strategies in emerging economies. Strategic Management Journal, 30: 61-80.

Miller, D., \& Shamsie, J. (1996). The resource-based view of the firm in two environments. Academy of Management Journal, 39: 519-543.

Murray, J. A. (1984). A concept of entrepreneurial strategy. Strategic Management Journal, 5: 1-13.

Narayanan, V.K., Zane, L.J., \& Kemmerer, B. (2011). The cognitive perspective in strategy: An integrative review. Journal of Management, 37: 305-351.

Navis, C., \& Glynn, M. A. (2010). How new market categories emerge: Temporal dynamics of legitimacy, identity, and entrepreneurship in satellite radio, 1990-2005. Administrative Science Quarterly, 55: 439-471.

Nelson, R.R. (1986). Institutions supporting technical advance in industry. American Economic Review, 76: 186189.

North, D.C. (1990). Institutions, Institutional Change and Economic Performance. Cambridge: Cambridge University Press.

Oberthur, S., \& Locke, O.S. (2011). Managing Institutional Complexity: Regime Interplay and Global Environmental Change. Boston: MIT Press.

Oliver, C. (1999). The influence of institutional and task environment relationships on organizational performance: The Canadian construction industry. Journal of Management Studies, 34: 99-124.

ONS. (2015). Environmental Taxes - 2014. Office for National Statistics, UK, 1 June.

Ostrom, E. (2005). Understanding Institutional Diversity. Princeton, NJ: Princeton University Press.

Ostrom, E. (2010). Beyond markets and states: Polycentric governance of complex economic systems. American Economic Review, 100: 1-33.

Ostrom, E., Schroeder, L., \& Wynne, S. (1993). Institutional Incentives and Sustainable Development: Infrastructure Policies in Perspective. Boulder, CO: Westview Press.

Payne, G.T., Kennedy, K.H. \& Davis, J.L. (2009). Journal of Small Business Management, 47: 421-442.

Peng, M.W., Sun, S.L., Pinkham, B., \& Chen, H. (2009). The institution-based view as a third leg for a strategy tripod. Academy of Management Perspective, 23(3): 63-81.

Peng, M.W., Wang, D.Y.L, \& Jiang, Y. (2008). An institution-based view of international business strategy: A focus on emerging economies. Journal of International Business Studies, 39: 920-936.

Persson, T. 2002. Do political institutions shape economic policy? Econometrica, 70: 883-905. 
Podsakoff, P.M., \& Organ, D.W. (1986). Self-reports in organizational research: Problems and prospects. Journal of Management, 12: 531-544.

Podsakoff, P.M., MacKenzie, S.B., Lee, J.-Y. \& Podsakoff, N.P. (2003). Common method biases in behavioral research: A critical review of the literature and recommended remedies. Journal of Applied Psychology, 88: 879-903.

Pollin, R. \& Zhu, A. (2006). Inflation and economic growth: A cross-country nonlinear analysis. Journal of Post Keynesian Economics, 28: 593-614.

Pontikes, E.G. \& Barnett, W.P. (2017). The coevolution of organizational knowledge and market technology. Strategy Science, 2: 64-82.

Porac, J., Thomas, H., \& Baden-Fuller, C. (1989). Competitive groups as cognitive communities: The case of Scottish knitwear manufacturers revisited. Journal of Management Studies, 26: 646-664.

Porter, E. (2018). Where are the start-ups? Loss of dynamism is impeding growth. New York Times, https://www.nytimes.com/2018/02/06/business/economy/start-ups-growth.html.

Porter, M.E. (1980). Competitive Strategy: Techniques for Analyzing Industries and Competitors. New York: Free Press.

Porter, M.E. (1985). Competitive Advantage: Creating and Sustaining Superior Performance. New York: Free Press.

Posen, H.E., Lee, J. \& Yi S. (2013). The power of imperfect imitation. Strategic Management Journal, 34: $149-164$.

Ringle, C.M., Wende, S., \& Will, A. (2005). SmartPLS 2.0. Hamburg: Germany.

Rueda-Manzanares, A., Aragon-Correa, A. \& Sharma, S. (2007). The influence of stakeholders on the environmental strategy of service firms: The moderating effects of complexity, uncertainty and munificence. British Journal of Management, 19: 185-203.

Rumelt, R.P. (1991). How much does industry matter? Strategic Management Journal, 12: 167-185.

Sabel, C., Herriegel, G. \& Kristensen, P.H. (2017). Regulation under uncertainty: The coevolution of industry and regulation. Regulation and Governance, 12: 371-394.

Schmalensee, R. (1985). Do markets differ much? The American Economic Review, 75: 341-351.

Scott, R. (1995). Institutions and Organizations. Thousand Oaks, CA: Sage.

Semadeni, M., Withers, M.C., \& Certo, S.T. (2014). The perils of endogeneity and instrumental variables in strategy research: Understanding through simulations. Strategic Management Journal, 35: 1070-1079.

Shamir, B., Zakay, E., \& Popper, M. (1998). Correlates of charismatic leader behavior in military units: Subordinates' attitudes, unit characteristics, and superiors' appraisals of leader performance. Academy of Management Journal, 41: 387-409.

Sharfman, M.P., \& Dean, J.W. (1991). Conceptualizing and measuring the organizational environment: A multidimensional approach. Journal of Management, 17: 681-700.

Shimizu, K. (2007). Prospect theory, behavioral theory, and the threat-rigidity hypothesis: Combinative effects on organizational decisions to divest formerly acquired units. Academy of Management Journal, 50(6):14951514.

Short, J.C., Ketchen, D.J., Palmer, T.B., \& Hult, G.T.M. (2007). Firm, strategic group, and industry influences on performance. Strategic Management Journal, 28: 147-167.

Sirmon, D. G., Hitt, M. A., Ireland, R. D., \& Gilbert, B. A. (2011). Resource orchestration to create competitive advantage: Breadth, depth, and life cycle effects. Journal of Management, 37: 1390-1412.

Sirmon, D.G., \& Hitt, M.A. (2009). Contingencies within dynamic managerial capabilities: Interdependent effects of resource investment and deployment on firm performance. Strategic Management Journal, 30: 1375-1394.

Sirmon, D.G., Hitt, M.A., \& Ireland, R.D. (2007). Managing firm resources in dynamic environments to create value: Looking inside the black box. Academy of Management Review, 32: 273-292.

Sirmon, D.G., Hitt, M.A., Arregle, J-L, Campbell, J. (2010). The dynamic interplay of capability strengths and weaknesses: Investigating the bases of temporary competitive advantage. Strategic Management Journal, 31: 1386-1409.

Sobel, R.S., Coyne, C.J. (2011). Cointegrating institutions: The time-series properties of country institutional measures. Journal of Law and Economics, 54: 111-134.

Sobrero, M. \& Roberts, E.B. (2002). Strategic management of supplier-manufacturer relations in new product development. Research Policy, 31: 159-182.

Spencer, J.W., \& Gómez, C. (2004). The relationship among national institutional structures, economic factors, and domestic entrepreneurial activity: A multicountry study. Journal of Business Research, 57(10):1098-1107 
Spender, J-C. (1989). Industry Recipes: An Inquiry into the Nature and Sources of Managerial Judgement. Oxford, UK Blackwell.

Spicer, A., McDermott, G. A., \& Kogut, B. 2000. Entrepreneurship and privatization in Central Europe: The tenuous balance between destruction and creation. Academy of Management Review, 25: 630-649.

Steensma, H.K., \& Corley, K.G. (2001). Organizational context as a moderator of theories on firm boundaries for technology sourcing. Academy of Management Journal, 44: 271-291.

Sun, P., Mellahi, K. \& Wright, M. (2012). The contingent value of corporate political ties. Academy of Management Perspectives, 26: 68-82.

Tan, J., \& Peng, M.W. (2003). Organizational slack and firm performance during economic transitions: Two studies from an emerging economy. Strategic Management Journal, 24: 1249-1263.

Tong, T., Alessandri, T., Reuer, J., \& Chintakananda, A. (2008). Sources of valuable growth options: A multicountry analysis. Journal of International Business Studies, 39: 387-405.

Tootelian, D.H., \& Gaedeke, R.M. (1987). Fortune 500 list revisited 12 years later: Still an endangered species for academic research? Journal of Business Research, 15: 359-363.

Uzzi, B. (1997). The sources and consequences of embeddedness for the economic performance of organizations: The network effect. American Sociological Review, 61: 674-698.

Wallis, J. (1999). Understanding the role of leadership in economic policy reform. World Development, $27:$ 39-53.

Whitney, L. (2013). Apple, Google, and the e-mail trail in the no-poaching case. c/net, https://c/net4.cbsistatic.com, January 23.

Young, S. \& Marais, M. (2012). A multi-level perspective of CSR reporting: The implications of national institutions and industry risk characteristics. Corporate Governance: An International Perspective, 20: $432-$ 450 
Table 1: Number of firms by industry and geographic region

\begin{tabular}{llllllll}
\multicolumn{2}{c}{ CHINA } & \multicolumn{3}{c}{ Europe } & US & \multicolumn{1}{c}{ Industry Description } \\
1 & Freq & \% & Freq & \% & Freq & $\%$ & Agriculture, forestry, and fisheries \\
2 & 3 & 0.7 & 0 & 0 & 0 & 0 & Mineral Industries \\
3 & 2 & 0.5 & 1 & 0.8 & 7 & 7 & Manufacturing \\
4 & 15 & 67.7 & 32 & 26.9 & 36 & 36 & Electric, gas, and sanitary services \\
5 & 17 & 3.4 & 6 & 5 & 5 & 5 & Construction Industries \\
6 & 0 & 0 & 2 & 1.7 & 9 & 9 & Environmental quality \\
7 & 16 & 3.6 & 5 & 0.8 & 4 & 4 & Transportation, Communication, and Utilities \\
8 & 42 & 9.6 & 8 & 6.7 & 6 & 6 & Retail Trade \\
9 & 2 & 0.5 & 1 & 0.8 & 0 & 0 & Finance and Insurance \\
10 & 17 & 3.9 & 13 & 10.9 & 6 & 6 & Real Estate \\
11 & 12 & 2.7 & 2 & 1.7 & 0 & 0 & Business Services \\
12 & 0 & 0 & 37 & 31.1 & 6 & 6 & Amusement and recreational \\
13 & 16 & 3.6 & 11 & 9.2 & 20 & 20 & Museums, art galleries, botanical \& zoological gardens \\
Total & 439 & 100 & 119 & 100 & 100 & 100 &
\end{tabular}


Table 2: Intercorrelation matrix with composite variables

\begin{tabular}{|c|c|c|c|c|c|c|c|c|c|c|c|c|c|}
\hline & Variable & Means & SDs & 1 & 2 & 3 & 4 & 5 & 6 & 7 & 8 & 9 & 10 \\
\hline 1 & Entrepreneurial & 0.00 & 0.81 & & & & & & & & & & \\
\hline 2 & Age & 2.57 & 1.09 & -0.10 & & & & & & & & & \\
\hline 3 & Dynamism & 0.09 & 0.04 & -0.12 & -0.18 & & & & & & & & \\
\hline 4 & Munificence & 0.20 & 0.07 & 0.16 & -0.35 & 0.30 & & & & & & & \\
\hline 5 & Institutions & 0.00 & 0.96 & -0.19 & 0.41 & -0.18 & -0.90 & & & & & & \\
\hline 6 & Performance & 0.00 & 0.84 & 0.42 & 0.04 & -0.12 & -0.10 & 0.06 & & & & & \\
\hline 7 & Size & 5.70 & 2.19 & 0.01 & 0.63 & -0.23 & -0.31 & 0.36 & 0.10 & & & & \\
\hline 8 & Slack & 0.00 & 0.40 & 0.21 & 0.25 & -0.14 & -0.38 & 0.36 & 0.46 & 0.31 & & & \\
\hline 9 & Relational Capital & 0.00 & 0.38 & 0.35 & -0.02 & -0.10 & 0.13 & -0.19 & 0.38 & -0.05 & 0.13 & & \\
\hline 10 & Synchronization & 0.00 & 0.63 & 0.48 & -0.16 & -0.02 & 0.27 & -0.33 & 0.34 & -0.04 & 0.12 & 0.44 & \\
\hline \multirow[t]{2}{*}{11} & Risk Aversion & 0.00 & 0.69 & 0.10 & 0.02 & -0.15 & 0.24 & -0.30 & 0.15 & 0.07 & 0.03 & 0.27 & 0.28 \\
\hline & Variable & Means & SDs & 1 & 2 & 3 & 4 & 5 & 6 & 7 & 8 & 9 & 10 \\
\hline 1 & Capability Advantage & 0.00 & 0.55 & & & & & & & & & & \\
\hline 2 & Age & 2.57 & 1.09 & -0.04 & & & & & & & & & \\
\hline 3 & Dynamism & 0.09 & 0.04 & -0.15 & -0.18 & & & & & & & & \\
\hline 4 & Munificence & 0.20 & 0.07 & -0.06 & -0.35 & 0.30 & & & & & & & \\
\hline 5 & Institutions & 0.00 & 0.96 & 0.00 & 0.41 & -0.18 & -0.90 & & & & & & \\
\hline 6 & Performance & 0.00 & 0.84 & 0.53 & 0.04 & -0.12 & -0.11 & 0.06 & & & & & \\
\hline 7 & Size & 5.70 & 2.19 & 0.06 & 0.63 & -0.23 & -0.31 & 0.36 & 0.11 & & & & \\
\hline 8 & Slack & 0.00 & 0.40 & 0.31 & 0.26 & -0.13 & -0.39 & 0.37 & 0.05 & 0.31 & & & \\
\hline 9 & Relational Capital & 0.00 & 0.38 & 0.41 & -0.01 & -0.10 & 0.10 & -0.17 & 0.37 & -0.05 & 0.14 & & \\
\hline 10 & Synchronization & 0.00 & 0.63 & 0.51 & -0.16 & -0.02 & 0.27 & -0.33 & 0.34 & -0.04 & 0.11 & 0.43 & \\
\hline 11 & Risk Aversion & 0.00 & 0.69 & 0.18 & 0.02 & -0.15 & 0.24 & -0.30 & 0.14 & 0.07 & 0.03 & 0.25 & 0.28 \\
\hline
\end{tabular}

Correlations in both matrices are significant at $\mathrm{p}<0.05$ when coefficients are larger than $|0.0765| ; n=658$

The means are 0.00 for the manifest variables 
Table 3 PLS results

\begin{tabular}{|c|c|c|c|c|c|c|c|}
\hline \multicolumn{3}{|c|}{ Capability Advantage Strategy (Model 1) } & \multicolumn{5}{|c|}{ Entrepreneurial Strategy (Model 2) } \\
\hline Hypotheses & Path & $\beta$ & $p$ value & Hypotheses & Path & $\beta$ & $p$ value \\
\hline $1 \mathrm{a}$ & Institutions $\rightarrow$ Dynamism & $-0.19 * *$ & 0.000 & $1 \mathrm{a}$ & Institutions $\rightarrow$ Dynamism & $-0.19 * * *$ & 0.000 \\
\hline $1 \mathrm{~b}$ & Institutions $\rightarrow$ Munificence & $-0.90 * * *$ & 0.000 & $1 \mathrm{~b}$ & Institutions $\rightarrow$ Munificence & $-0.90 * * *$ & 0.000 \\
\hline $2 \mathrm{a}$ & Dynamism $\rightarrow$ Capability Adv. & $-0.06+$ & 0.090 & $2 \mathrm{~b}$ & Dynamism $\rightarrow$ Entrepreneurial & $-0.13^{* *}$ & 0.002 \\
\hline $2 \mathrm{c}$ & Dynamism $\times$ Rel. Cap. $\rightarrow$ Cap. Adv. & $0.08^{*}$ & 0.025 & $2 \mathrm{~d}$ & Dynamism $\times$ Rel. Cap. $\rightarrow$ Entrepreneurial & $0.08 *$ & 0.042 \\
\hline $3 a$ & Munificence $\rightarrow$ Capability Adv. & $-0.13 * * *$ & 0.001 & $3 \mathrm{~b}$ & Munificence $\rightarrow$ Entrepreneurial & $0.17 * * *$ & 0.000 \\
\hline Control & Rel. Cap. $\rightarrow$ Capability Adv. & $0.19 * * *$ & 0.000 & Control & Rel. Cap. $\rightarrow$ Entrepreneurial & $0.16^{* * *}$ & 0.000 \\
\hline Control & Synch. $\rightarrow$ Capability Adv. & $0.42 * * *$ & 0.000 & Control & Synchronization $\rightarrow$ Entrepreneurial & $0.36^{* * * *}$ & 0.000 \\
\hline Control & Age $\rightarrow$ Capability Adv. & $-0.10 * *$ & 0.017 & Control & Age $\rightarrow$ Entrepreneurial & $-0.08^{*}$ & 0.038 \\
\hline Control & Risk Aversion $\rightarrow$ Capability Adv. & 0.02 & 0.523 & Control & Risk Aversion $\rightarrow$ Entrepreneurial & $-0.12 * * *$ & 0.002 \\
\hline Control & Slack $\rightarrow$ Capability Adv. & $0.19^{* * * *}$ & 0.000 & Control & Slack $\rightarrow$ Entrepreneurial & $0.20 * * *$ & 0.000 \\
\hline Control & Size $\rightarrow$ Capability Adv. & 0.04 & 0.214 & Control & Size $\rightarrow$ Entrepreneurial & 0.06 & 0.131 \\
\hline Control & Dynamism $\rightarrow$ Synch. & $-0.11 * *$ & 0.006 & Control & Dynamism $\rightarrow$ Synch & $-0.11 * *$ & 0.006 \\
\hline Control & Munificence $\rightarrow$ Synch. & 0.30 *** & 0.000 & Control & Munificence $\rightarrow$ Synch & $0.31 * * *$ & 0.000 \\
\hline Control & Age $\rightarrow$ Performance & -0.03 & 0.328 & Control & Age $\rightarrow$ Performance & -0.05 & 0.220 \\
\hline Control & Dynamism $\rightarrow$ Performance & \begin{tabular}{|l|}
-0.01 \\
\end{tabular} & 0.706 & Control & Dynamism $\rightarrow$ Performance & 0.01 & 0.721 \\
\hline Control & Munificence $\rightarrow$ Performance & 0.00 & 0.899 & Control & Munificence $\rightarrow$ Performance & $-0.09 * *$ & 0.016 \\
\hline Control & Risk Aversion $\rightarrow$ Performance & 0.02 & 0.498 & Control & Risk Aversion $\rightarrow$ Performance & 0.05 & 0.137 \\
\hline Control & Capability Adv. $\rightarrow$ Performance & $0.33^{* * * *}$ & 0.000 & Control & Entrepreneurial $\rightarrow$ Performance & $0.23 * * *$ & 0.000 \\
\hline Control & Relational Capital $\rightarrow$ Performance & $0.16^{* * * *}$ & 0.001 & Control & Relational Capital $\rightarrow$ Performance & $0.21 * * *$ & 0.000 \\
\hline Control & Size $\rightarrow$ Performance & 0.01 & 0.773 & Control & Size $\rightarrow$ Performance & 0.00 & 0.872 \\
\hline Control & Slack $\rightarrow$ Performance & $0.34 * * *$ & 0.000 & Control & Slack $\rightarrow$ Performance & $0.35^{* * * *}$ & 0.000 \\
\hline Control & Synch $\rightarrow$ Performance & 0.05 & 0.144 & Control & Synch $\rightarrow$ Performance & $0.10^{*}$ & 0.020 \\
\hline $\mathrm{R}^{2}$ Performance & 0.41 & & & & 0.39 & & \\
\hline
\end{tabular}

$\mathrm{R}^{2}$ Performance 0.41

$$
+\mathrm{P}<.10 ; * \mathrm{p}<0.05 ; * * \mathrm{p}<0.01 ; * * * \mathrm{p}<0.001
$$


Figure 1

Theoretical model

National Formal

Institutions

Economic

Political

Regulatory

H1a-

H1b-

Indicates a controlled relationship

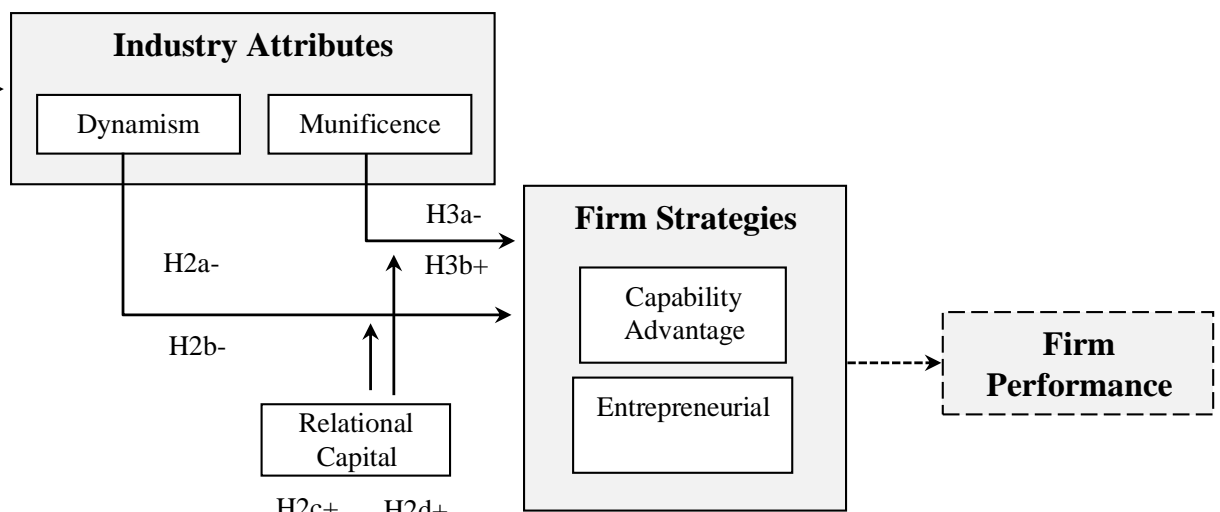

Commented [AJ1]: I made several changes but they do not appear in Track changes mode as this is a figure. I found th

Check that I got it right... Thanks. 
APPENDIX 1: Convergent and discriminant validity analyses for PLS models

$\begin{array}{llcllllll} & \text { Variable } & \text { Composite Reliability } & 1 & 2 & 3 & 4 & 5 & 6 \\ 1 & \text { Institutions } & 0.93 & \mathbf{0 . 8 0} & & & & & \\ 2 & \text { Ent. Opportunity } & 0.90 & 0.04 & \mathbf{0 . 7 5} & & & & \\ 3 & \text { Performance } & 0.83 & 0.00 & 0.18 & \mathbf{0 . 7 1} & & & \\ 4 & \text { Slack } & 0.75 & 0.13 & 0.04 & 0.21 & \mathbf{0 . 6 1} & & \\ 5 & \text { Relational Capital } & 0.65 & 0.04 & 0.12 & 0.15 & 0.02 & \mathbf{0 . 5 2} & \\ 6 & \text { Synchronization } & 0.91 & 0.11 & 0.23 & 0.12 & 0.01 & 0.20 & \mathbf{0 . 7 2} \\ 7 & \text { Age } & & 0.17 & 0.01 & 0.00 & 0.06 & 0.00 & 0.02 \\ 8 & \text { Dynamism } & & 0.03 & 0.01 & 0.01 & 0.02 & 0.01 & 0.00 \\ 9 & \text { Munificence } & & 0.81 & 0.03 & 0.01 & 0.15 & 0.02 & 0.07 \\ 10 & \text { Size } & 0.13 & 0.00 & 0.01 & 0.10 & 0.00 & 0.00 \\ 11 & \text { Risk Aversion } & & 0.09 & 0.01 & 0.06 & 0.00 & 0.07 & 0.08\end{array}$

Values in bold show the average variance extracted (AVE) by constructs. The other values are the squared correlations (Chin, 2010) or the composite reliability.

$\begin{array}{llcllllll} & \text { Variable } & \text { Composite Reliability } & 1 & 2 & 3 & 4 & 5 & 6 \\ 1 & \text { Institutions } & 0.93 & \mathbf{0 . 8 0} & & & & & \\ 2 & \text { Capability Adv } & 0.90 & 0.00 & \mathbf{0 . 6 8} & & & & \\ 3 & \text { Performance } & 0.83 & 0.00 & 0.28 & \mathbf{0 . 7 1} & & & \\ 4 & \text { Slack } & 0.75 & 0.13 & 0.10 & 0.22 & \mathbf{0 . 6 2} & & \\ 5 & \text { Relational Capital } & 0.67 & 0.03 & 0.17 & 0.14 & 0.02 & \mathbf{0 . 5 3} & \\ 6 & \text { Synchronization } & 0.91 & 0.11 & 0.26 & 0.11 & 0.01 & 0.19 & \mathbf{0 . 7 2} \\ 7 & \text { Age } & & 0.17 & 0.00 & 0.00 & 0.07 & 0.00 & 0.03 \\ 8 & \text { Dynamism } & & 0.03 & 0.02 & 0.01 & 0.02 & 0.01 & 0.00 \\ 9 & \text { Munificence } & & 0.81 & 0.00 & 0.01 & 0.15 & 0.01 & 0.07 \\ 10 & \text { Size } & & 0.13 & 0.00 & 0.01 & 0.10 & 0.00 & 0.00 \\ 11 & \text { Risk Aversion } & & 0.09 & 0.03 & 0.02 & 0.00 & 0.06 & 0.08\end{array}$

Values in bold show the average variance extracted (AVE) by constructs. The other values are the squared correlations (Chin, 2010) or the composite reliability. 
APPENDIX 2: PLOTS OF INTERACTIONS

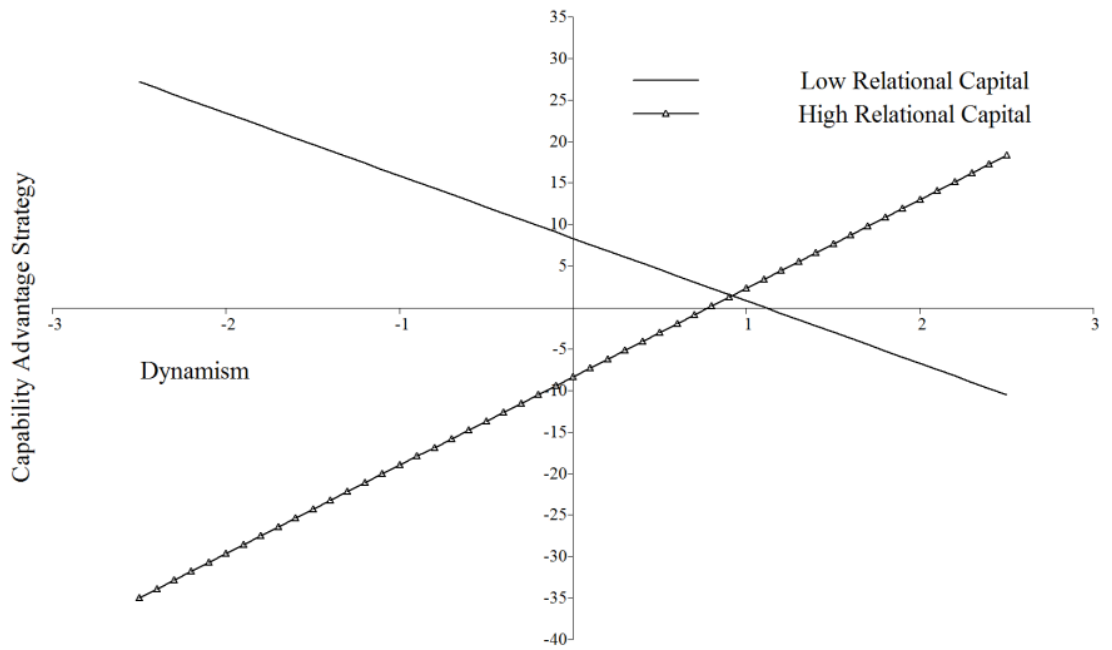

Figure 2

The interactive effect of industry dynamism and relational capital on capability advantage strategy

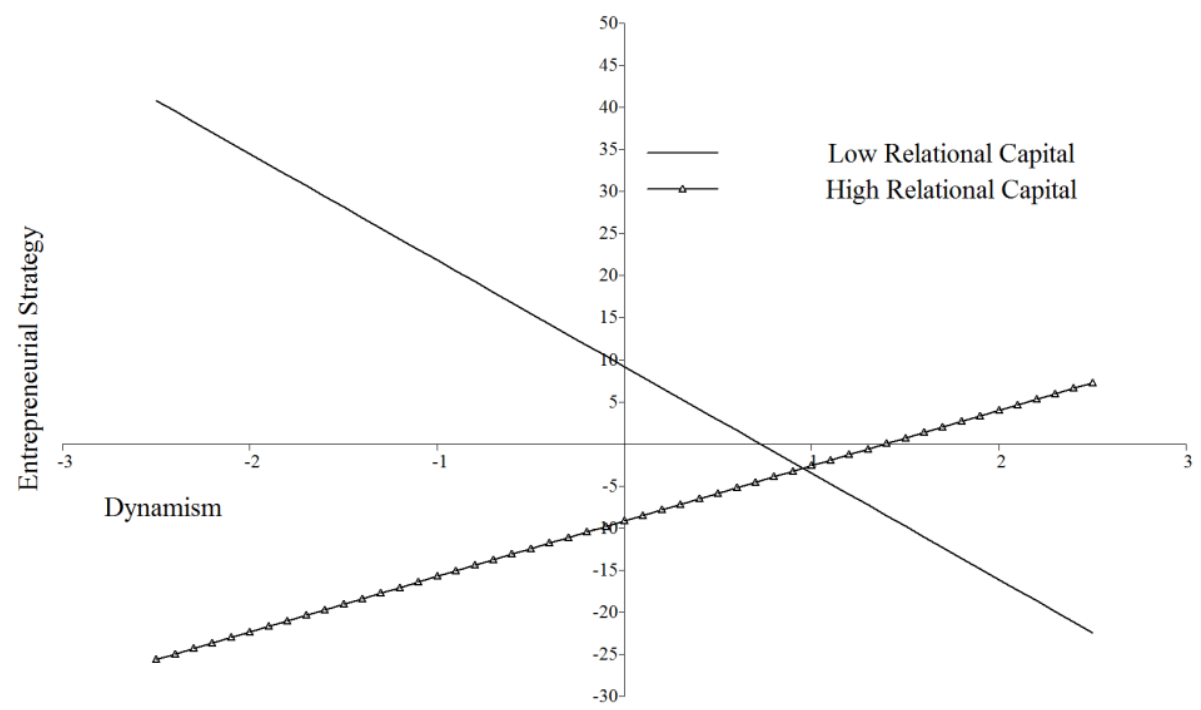

Figure 3

The interactive effect of industry dynamism and relational capital on entrepreneurial strategy 